\title{
HEATING AND MELTING OF FLOATING ICE SHELVES
}

\author{
By H. WEXLER \\ (Chief Scientist, U.S.-I.G.Y. Antarctic Program, National Academy of Sciences, \\ Washington, D.C.)
}

\begin{abstract}
Based on an observed temperature profile through the Ross Ice Shelf at Little America and partial profiles in the Maudheim Is-shelf and the Filchner Ice Shelf near the Ellsworth I.G.Y. station, various models of heating with and without melting from below are analysed to find the residence time of the respective ice shelves over the ocean. Estimated movements are compared with observed shelf movements seaward. 100 and $200 \mathrm{yr}$. melting rates for an ice shelf initially $20.5^{\circ} \mathrm{C}$. below the freezing point of sea-water are found as functions of the deviation of sea-water from its freezing point and the eddy conductivity of the ocean below the ice shelf. Steady-state solutions based on constant accumulation and sinking in an ice shelf of constant thickness are discussed.

The effect of heating of an ice shelf from above and below as it moves to a warmer atmospheric environment is described and it is concluded that the decreasing temperature with depth found only in the Ellsworth ice is a result of its rapid motion from the cold region to the south-east of the station (Coats Land).
\end{abstract}

RÉsumé. En utilisant des températures observées dans des profils à travers le Ross Ice Shelf à Little America et dans des profils partiels du Maudheim Is-shelf et du Filchner Ice Shelf près de la station A.G.I. Ellsworth, on a examiné des modèles variés de chauffage avec, ou sans, fusion en-dessous, pour chercher à déterminer la durée du séjour de la plateforme de glace sur l'océan à ces endroits.

On a comparé les mouvements calculés avec les mouvements observés de la plateforme vers la mer. Les vitesses moyennes de fusion pendant 100 ans et pendant 200 ans, pour une plateforme dont la température était à l'origine $20,5^{\circ} \mathrm{C}$ au-dessous du point de congélation de l'eau de mer, sont calculées comme fonctions de la déviation de la température du point de congélation et le coefficient de la transmission de la chaleur par convection de l'eau de mer se trouvant en-dessous de la plateforme. On discute des solutions pour des températures à l'état stationnaire, en présumant une vitesse constante d'affaissement dans une plateforme de glace d'épaisseur également constante.

On décrit l'effet que produit le chauffage de la plateforme d'en dessus et d'en dessous pendant qu'elle chemine vers un milieu atmosphérique plus doux, et on en conclut qu'une température décroissante suivant la profondeur-phénomène qui ne se produit que dans la glace de Ellsworth-s'explique par la rapidité du cheminement de cette glace de la région froide au sud-est de la station (Coats Land).

Zusammenfassung. Auf Grund eines beobachteten Temperaturprofils durch das Ross Ice Shelf bei Little America sowie Teilprofile durch das Maudheim Is-shelf und das Filchner Ice Shelf bei der Ellsworth I.G.Y. Station werden verschiedene Beispiele des Erwärmens mit und ohne Schmelzen von unten untersucht, um die Aufenthaltszeit der betreffenden Schelfeismassen über dem Meeresspiegel festzustellen. Abgeschätzte Bewegungen werden mit beobachteten Schelfbewegungen seewärts verglichen. Schmelzwerte über 100 bzw. 200 Jahre für ein Schelfeis ursprünglich $20,5^{\circ} \mathrm{C}$ unter dem Gefrierpunkt des Meerwassers werden als Funktionen sowohl der Abweichung des Meeres von dessen Gefrierpunkt als auch der Wirbelleitfähigkeit des Meeres unter dem Schelfeis festgestellt. Ergebnisse für den stationären Stand auf Grund ständigen Zuwachses und Sinkens für ein Schelfeis bei konstanter Dichte werden besprochen.

Die Auswirking des Erwärmens eines Schelfeises von oben und unten, während es sich nach einer atmosphärisch wärmeren Lage bewegt, wird beschrieben, und der Verfasser ziecht den Schluss, dass die abnehmende Temperatur bei Tiefe, die nur im Ellsworth-Schelfeis vorkommt, eine Folge seiner schnellen Bewegung von der kalten Region südöstlich der Station (Coats Land) ist.

Shall we learn that you come from the mountains? Shall we call you a frozen sea? Shall we sail to the Northward and leave you, still a Secret for ever to be?

To the Great Barrier by E. H. Shackleton, 1902

A notable contribution to the structure of the ice shelf at the Little America V I.G.Y. station, Antarctica, was made in November and December 1958, when a $14.6 \mathrm{~cm}$. wide hole was drilled to a depth of $255 \mathrm{~m}$. or to within about $5 \mathrm{~m}$. of the bottom. This was done by a U.S. Army-S.I.P.R.E. drill team as part of the U.S.-I.G.Y. Antarctic Program. Io cm. cores and temperatures were obtained to the bottom of the hole. Details of the drill operation and measurement of temperature are being published. ${ }^{\mathrm{I}}$ In the present paper an attempt will be made to interpret the Little America vertical temperature profile in terms of real heat and latent heat of fusion supplied to the ice shelf by the underlying ocean, using as supplementary or verifying data, observations of ice thickness and motion. Also, a steady-state solution associated with vertical motions will be discussed. Comparisons will be made with the ice shelves near Maudheim and the Ellsworth I.G.Y. station. 


\section{The Observed Temperature Profile}

In Fig. I are plotted the observed temperatures of the Little America hole (lat. $78^{\circ} \mathrm{I} \mathrm{I}^{\prime} \mathrm{S}$., long. $162^{\circ}{ }^{\prime} 0^{\prime}$ W.; $44 \mathrm{~m}$. a.s.l.). The temperatures are believed to be accurate to $\pm 0 \cdot \mathrm{I}^{\circ} \mathrm{C}$. The snow temperature of $-22 \cdot 3^{\circ} \mathrm{C}$. at ro $\mathrm{m}$. depth was measured $25 \mathrm{~m}$. away from the deep hole by $\mathrm{H}$. Neuberg. The $-22^{\circ} \mathrm{C}$. snow temperature at $12 \cdot 2 \mathrm{~m}$. depth was observed below the floor of the snow laboratory a few meters from the deep hole. Four points, designated by squares, represent air temperatures at designated depths in the hole where the thermometer had been allowed to come to equilibrium for 12 or more hours. The remaining points, designated by circles, are temperatures observed by a thermometer in contact with the bottom of the hole and presumably embedded in a thin layer of ice "dust" remaining after the drilling bit was withdrawn. Both the air and snow temperatures agree quite well in the region of overlap between 60 and $I_{1} 0 \mathrm{~m}$. However, the two air temperatures at $12 \cdot 2$ and $43 \mathrm{~m}$. appear to be slightly too high, perhaps caused by the steel casing extending $4 \mathrm{I} \mathrm{m}$. into the hole.

The temperature increases with depth, more and more rapidly with increasing depth. The bottom temperature of $-4.4^{\circ} \mathrm{C}$. was observed at $250 \mathrm{~m}$.; the drilling was continued to $255 \mathrm{~m}$. where the ice cores still showed no signs of salinity. Later, sea-water seeped into the hole and froze. Re-drilling was attempted but no temperatures at greater depth were obtained. The extrapolation of a smooth curve going through the observed points intersects $-\mathrm{I} \cdot 8^{\circ} \mathrm{C}$., the freezing point of salt water of 33 parts per thousand salinity, at $259 \mathrm{~m}$. depth,* which is the upper limit of ice thickness that N. A. Ostenso detected by seismic shooting near the drill hole in November 1958.

\section{Computed Temperature Profiles with No Melting}

A curve drawn through the observed temperatures in Fig. I appears to depart from the near-straight line quasi-equilibrium temperature profile which would result if an ice shelf, $259 \mathrm{~m}$. thick, initially isothermal at $-22 \cdot 3^{\circ} \mathrm{C}$., had remained over a $-\mathrm{I} \cdot 8^{\circ} \mathrm{C}$. ocean for $400 \mathrm{yr}$. without melting or vertical motions. Other profiles are drawn for residence times of 200 , 100 and 50 yr., with no melting. $†$ Curve "a", drawn for $100 \mathrm{yr}$. residence time over the ocean, agrees so well with the observed temperatures (mean deviation of only $0.85^{\circ} \mathrm{C}$.), that it is tempting to state that the problem is solved, that Little America $\mathrm{V}$ is on an ice shelf that has been over the ocean for $100 \mathrm{yr}$., that in this interval the ice shelf has moved northward from the nearest land, Roosevelt Island, whose closest point to Little America V is $60 \mathrm{~km}$. (see Fig. 5, p. 635). This would mean a movement of $0.60 \mathrm{~km}$. $/ \mathrm{yr}$. or $\mathrm{I} \cdot 65 \mathrm{~m}$./day, a value in quite reasonable agreement with an earlier estimate by Gould. ${ }^{2}$ In essence this analysis would mean that the Little America V ice shelf is just an ice "run-off" from Roosevelt Island, whose ice cover is believed to be an ice cap formed from local accumulation on the island and not part of the original Ross Ice Shelf which moved over the island in its northward
motion. 3

However, the assumption of no melt during the century of residence over the ocean is a worrisome matter which requires further consideration. (The possibility of significant accretion of ice from below because of sea-water freezing is eliminated because of lack of saline ice within $5 \mathrm{~m}$. of the bottom of the ice.) Our doubts are further increased by the fact that the ice at the northern tip of Roosevelt Island is about $400 \mathrm{~m}$. thick, ${ }^{4}$ greater than that found at Little America V, $259 \mathrm{~m}$. If this is the same ice layer moving northward one would have to account for the vertical loss of I4I m. of old ice plus $20 \mathrm{~m}$. of accumulated ice during the century the ice took to move $60 \mathrm{~km}$. to the north. The effect of melting at the bottom must be considered; no appreciable melting and run-off occur at the top surface in summer, since the

* Actually, if account were taken of the pressure lowering of the freezing point, the temperature should be $-2.0^{\circ} \mathrm{C}$., but this would decrease the extrapolated depth by only $0.8 \mathrm{~m}$.

$\dagger$ These computations are outlined in Appendix A (see p. 643). 
average December-January surface air temperature at Little America V is $-6 \cdot \mathrm{I}^{\circ} \mathrm{C}$. Also there is a possibility that sinking motions caused by horizontal divergence of the ice shelf 5 could account for some of the thinning of Roosevelt Island ice in its motion northward; this effect will be discussed later.

\section{Computed Temperature Profile with Bottom Melting-I}

In Fig. I we add a new curve " $b$ " for Ioo yr. of heating and bottom melting. This new curve is computed under the assumption that the energy is conducted to the bottom of the ice from an ocean whose temperature stays "just above" the $-\mathrm{I} \cdot 8^{\circ} \mathrm{C}$. freezing point of 33 parts per thousand saline sea-water and that this energy is partitioned equally between heating the ice shelf and melting a portion of it.* In I $00 \mathrm{yr} .9 \cdot 3 \mathrm{~m}$. of ice are melted and the temperature profile becomes the curve designated by curve " $b$ " in Fig. I. This curve agrees somewhat better with the observed temperatures (see Table I) but both computed curves

Table I. Little America V Hole, Observed Temperatures and Computed Minus Observed Deviations ( ${ }^{\circ} \mathrm{C}$.)

$\begin{array}{cc}\begin{array}{c}\text { Depth } \\ \mathrm{m} .\end{array} & \begin{array}{c}\text { Observed } \\ \text { Temp. }\end{array} \\ & { }^{\circ} \mathrm{C} . \\ 10 \cdot 0 & -22 \cdot 30 \\ 12 \cdot 2 & -22 \cdot 00 \\ 42 \cdot 7 & -21 \cdot 60 \\ 61 \cdot 0 & -21 \cdot 54 \\ 84 \cdot 1 & -21 \cdot 10 \\ 96 \cdot 0 & -20 \cdot 68 \\ 105 \cdot 8 & -20 \cdot 22 \\ 121 \cdot 9 & -19 \cdot 47 \\ 138 \cdot 7 & -18 \cdot 57 \\ 152 \cdot 1 & -17 \cdot 69 \\ 170 \cdot 1 & -16 \cdot 28 \\ 188 \cdot 1 & -14 \cdot 89 \\ 203 \cdot 6 & -13 \cdot 02 \\ 222 \cdot 5 & -10 \cdot 24 \\ 228 \cdot 6 & -9 \cdot 26 \\ 233 \cdot 2 & -8 \cdot 37 \\ 239 \cdot 6 & -7 \cdot 05 \\ 243 \cdot 2 & -6 \cdot 06 \\ 24.5 & -4 \cdot 40 \\ (259 \cdot 1) & (-1.80) \\ \text { Mean deviation } & \\ (\text { regardless of sign) }\end{array}$

\begin{tabular}{cc} 
Curve " $a$ " & $\begin{array}{c}\text { Curve " } b \text { " } \\
\text { Ioo yr. }\end{array}$ \\
no melt & $9.3 \mathrm{~m}$. melt \\
- & - \\
- & - \\
-0.5 & -0.5 \\
-0.2 & -0.4 \\
-0.3 & -0.5 \\
-0.4 & -0.6 \\
-0.4 & -0.8 \\
-0.5 & -0.9 \\
-0.4 & -0.9 \\
-0.3 & -0.8 \\
0.5 & -0.3 \\
0.9 & 0.2 \\
1.3 & 0.6 \\
1.7 & 1.2 \\
2.0 & 1.3 \\
1.7 & 1.3 \\
1.5 & 1.0 \\
1.3 & 0.8 \\
0.6 & 0.6 \\
\hline $0.85{ }^{\circ} \mathrm{C}$. & $-0.75{ }^{\circ} \mathrm{C}$.
\end{tabular}

Curve "c"
IOo yr.
$24.4 \mathrm{~m}$. melt
-
-0.6
$-0 \cdot 5$
$-0 \cdot 9$
-0.8
$-1 \cdot 0$
$-1 \cdot 2$
$-1 \cdot 4$
$-1 \cdot 3$
$-1 \cdot 1$
$-0 \cdot 4$
$0 \cdot 0$
$0 \cdot 3$
0.6
$0 \cdot 7$
$1 \cdot 0$
0.6
0.3
$-0.75{ }^{\circ} \mathrm{C}$.

Curve "d"
200 yr.
I20.I m. melt
-
-0.4
-0.2
-0.2
-0.3
-0.5
-0.6
-0.8
-0.8
-0.6
0.0
0.0
0.3
0.6
0.7
$1 \cdot 0$
0.6
0.3
$0.466^{\circ} \mathrm{C}$.
Curve " $e$ " steady-state, $50 \mathrm{~cm} \cdot \mathrm{yr} .^{-1}$ sinking

suffer from the same defect of large positive departures from the observed temperatures in the lower half of the ice shelf. In fact, in the lowest $30 \mathrm{~m}$., the observed temperatures fall almost exactly on the $50 \mathrm{yr}$. no melt curve.

The melting of $9.3 \mathrm{~m}$. of ice in $100 \mathrm{yr}$., or an average of $9.3 \mathrm{~cm}$. $/ \mathrm{yr}$. would be only 6 per cent of the observed thinning if the ice had moved from Roosevelt Island, and less than half of the annual water accumulation at Little America V. Let us now see what the result would be without arbitrarily assuming equipartition of energy into heating and melting.

\section{Computed Temperature Profile with Bottom Melting-II}

The rate of melting and heating of an ice shelf lying on an ocean will be influenced by the rate at which energy is transported to the ice bottom by the warmer ocean. The ice-water interface is assumed to remain always at the freezing point of sea-water of salinity 33 parts per thousand, or $-\mathrm{I} \cdot 8^{\circ} \mathrm{C}$. If the water far below the ice bottom (or more precisely at a depth corresponding to the bottom of the ice before melting began; see Appendix B) is kept at a temperature, $\Delta T$, above the freezing point, then the heat transport to the ice bottom will be

* These calculations are outlined in Appendix B (see p. 644). 


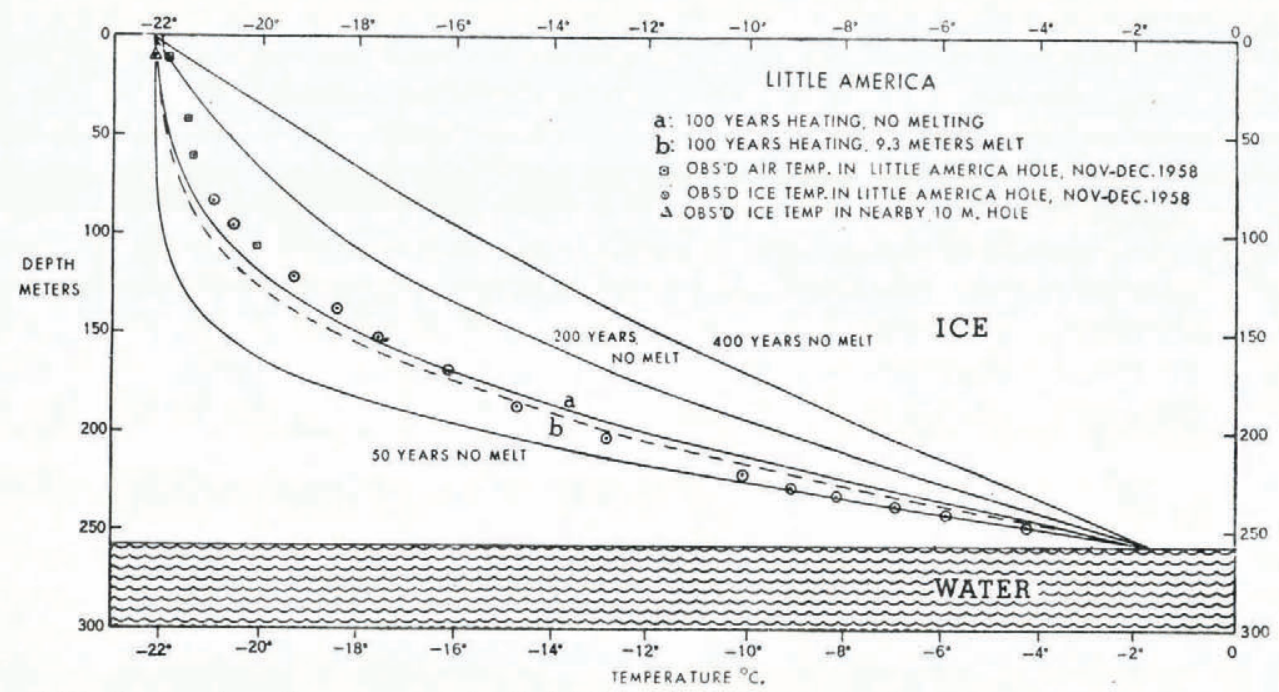

Fig. 1. Little America observed temperatures in ice shelf designated by points. Computed temperatures based on heating with and without melting

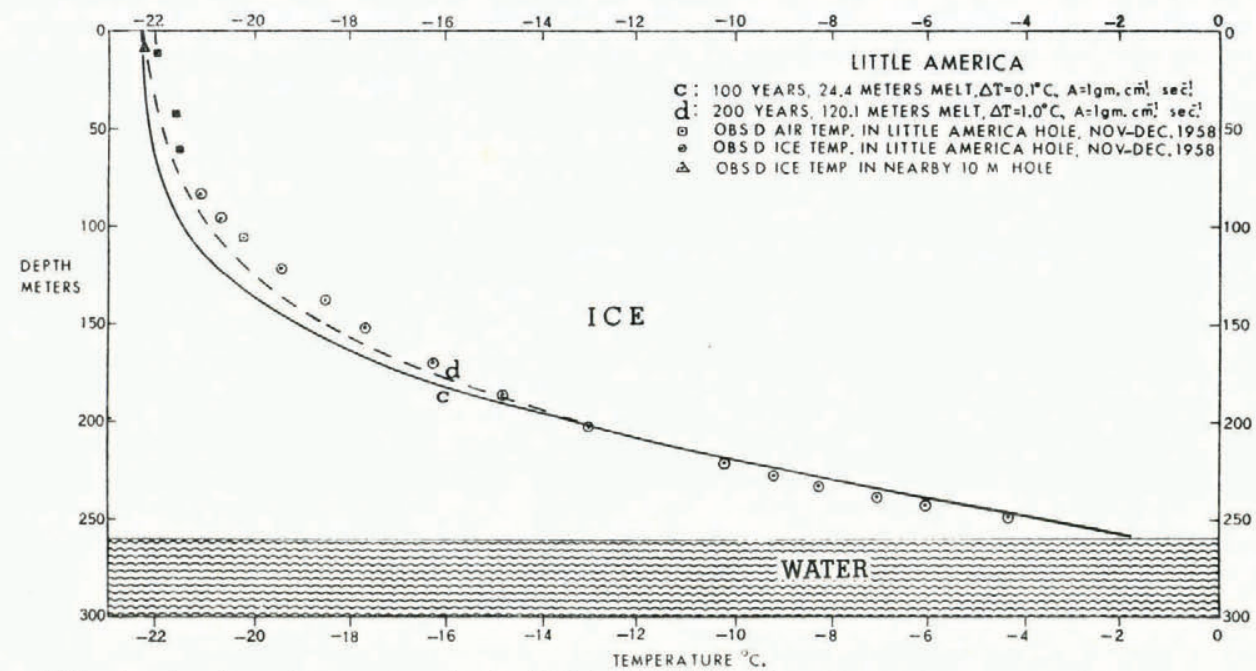

Fig. 2. Little America observed temperatures in ice shelf designated by points. Computed temperatures based on heating with melting

conducted primarily by eddies created by turbulent motions in the ocean currents under the ice.

One way of measuring the coefficient of eddy conductivity in the oceans is by observing the variations of the seasonal amplitude and lag of temperatures at various depths. In the open ocean this can vary from $16 \cdot 4$ to $2 \cdot 1 \mathrm{~g}$. $\mathrm{cm}^{-1} \mathrm{sec}^{-1}$ at o to $50 \mathrm{~m}$. in the Bay of Biscay and from 78 to $23 \mathrm{~g}$. cm. ${ }^{-1} \mathrm{sec}^{-1}$ in the Kuroshio Current. ${ }^{6}$ The strong current of the Kuroshio Current would lead to greater eddying motions than in the Bay of Biscay and the latter would probably also have stronger eddying motions than the water under the Ross Ice Shelf. Hence a value of eddy conductivity equal to $\mathrm{I}$ g. $\mathrm{cm} .^{-1} \mathrm{sec} .^{-\mathrm{I}}$ was initially assumed for the calculations outlined in Appendix B.

In Fig. 2 is drawn curve "c" computed under the assumption that ice, initially isothermal 
at $-22 \cdot 3^{\circ} \mathrm{C}$., is in contact for $100 \mathrm{yr}$. with water whose deep temperature is $-\mathrm{I} \cdot 7^{\circ} \mathrm{C}$., or $\mathrm{O} \cdot \mathrm{I}^{\circ} \mathrm{C}$. above the freezing point, and which has an eddy conductivity of $\mathrm{I} \mathrm{g} . \mathrm{cm} .^{-1} \mathrm{sec}^{-1}$. During these 100 yr. $24.4 \mathrm{~m}$. of ice would be melted from the bottom. Curve "c" is in fairly good agreement with the observed temperatures below I $75 \mathrm{~m}$. but has quite large negative deviations above.

In Fig. 2, curve "d" is plotted under the assumption that ice, initially isothermal at $-22.3^{\circ} \mathrm{C}$., is in contact for $200 \mathrm{yr}$. with water whose temperature below the ice bottom is $-0.8^{\circ} \mathrm{C}$. and which has an eddy conductivity of $\mathrm{r}$ g. $\mathrm{cm} .^{-1} \mathrm{sec} .^{-1}$. During this $200 \mathrm{yr}$. period $120.1 \mathrm{~m}$. of ice would be melted from the bottom. The temperature profile is given by curve "d" which agrees better with the observed temperatures than any of the previous computed curves.

Of all four curves constructed thus far, curve " $d$ " fits the observed points best with curves "b" and "c" next and curve "a" last.

It should be emphasized that the four curves discussed herein were computed under the assumption that there exists in the ice shelf no vertical motions. Because of the constant thickness of the Maudheim Is-shelf despite an annual accumulation of $40 \mathrm{~cm}$. water equivalent, Robin has stressed this process and has shown that there exists a steady-state temperature profile which is not linear. ${ }^{5}$

Let the origin of the $x$-axis be located in the surface of an ice shelf of thickness $H$, with $x$ positive downward.

Assume that the shelf thickness, $H$, remains constant by an annual accumulation, $w_{0}$, which is off-set by a sinking of the ice layers at a speed of $w_{0}$ and a melting rate at the bottom of $w_{\mathrm{o}} \mathrm{cm} . \mathrm{yr}^{-1}$. If the ice layers move with no change of temperature, then

$$
\frac{\partial T}{\partial t}=-w_{0} \frac{\partial T}{\partial x}, \quad t=\text { time, }
$$

represents the local change of temperature.

If conduction of heat occurs, then ( $I$ ) becomes

$$
\frac{\partial T}{\partial t}=-w_{0} \frac{\partial T}{\partial x}+\kappa \frac{\partial^{2} T}{\partial x^{2}}
$$

where $\kappa=K / \rho c=\mathrm{I} \cdot \mathrm{I} 5 \times 10^{-2}$ c.g.s. units is the thermal diffusivity of ice,

$K=5.3 \times 10^{-3}$ is its thermal conductivity,

$\rho=0.9^{2}$ is its density,

$c=0.5$ is its specific heat.

Equation (2) has been solved by Benfield 7 in finding the temperature of an accumulating snow field subjected to a periodic surface temperature.

For a steady-state $\frac{\partial T}{\partial t}=0$, and (2) becomes

$$
\frac{d^{2} T}{d x^{2}}-\frac{w_{0}}{\kappa} \frac{d T}{d x}=0
$$

which can be easily solved if $\kappa$ and $w_{0}$ are independent of $x$. The solution is

$$
T=C_{1}+C_{2} \exp (-a x)
$$

where $a=-w_{0} / \kappa$ and $C_{\mathrm{r}}$ and $C_{2}$ are constants.

Although not written explicitly in his 1955 paper, this is Robin's solution for the special case of bottom melting equal to surface accumulation. Introducing the boundary conditions: $T=T_{\mathrm{o}}$ at $x=\mathrm{o}$ and $T=T_{H}$ at $x=H$, the solution becomes

$$
\left(T-T_{0}\right) /\left(T_{H}-T_{0}\right)=[\mathrm{I}-\exp (-a x)] /[\mathrm{I}-\exp (-a H)] \text {. }
$$

Taking $\mathrm{T}_{0}=-22 \cdot 3^{\circ} \mathrm{C}$. and $T_{H}=-\mathrm{I} \cdot 8^{\circ} \mathrm{C}$., two curves are plotted in Fig. 3 : curve "e" for $w_{0}=50 \mathrm{~cm}$. yr. ${ }^{-1}$ and curve "f $\mathrm{f}$ " for $w_{0}=20 \mathrm{~cm}$. yr. ${ }^{-1}$. The respective equations are:

$$
\begin{aligned}
& \text { Curve "e": } T=-22 \cdot 9+0.619 \exp \left(0.13^{6} 5^{\left.x \times 10^{-3}\right)}\right. \\
& \text { Curve "f": } T=-28.9+6.62 \exp \left(0.545^{\left.x \times 10^{-4}\right)}\right.
\end{aligned}
$$


As may be seen in Fig. 3, the observed temperatures of the Little America hole fit curve " $e$ " quite well but depart widely from curve " $\mathrm{f}$ ". As shown by Table $\mathrm{I}$, the average deviation of the points from curve " $\mathrm{e}$ " is $0.18^{\circ} \mathrm{C}$. with the maximum deviation of only $0.5{ }^{\circ} \mathrm{C}$.

At Little America V, the average annual accumulation is about $20 \mathrm{~cm}$. ice equivalent. Suppose that the ice shelf thickness remains constant despite this annual accumulation; then the ice layers in the shelf must sink at a rate of $20 \mathrm{~cm}$. per annum (except for the surface layer where greater motions occur because of compaction of the snow and firn). But the resulting steady-state temperature profile, curve "f", fits the observed temperatures very poorly, while curve "e" drawn-for a $50 \mathrm{~cm}$. per annum sinking, fits the observed points almost perfectly. As is well known the accumulation apparently can vary greatly in short distances. For example, at Little America I, located $60 \mathrm{~km}$. south-west of Little America V, $20 \mathrm{~m}$. of two

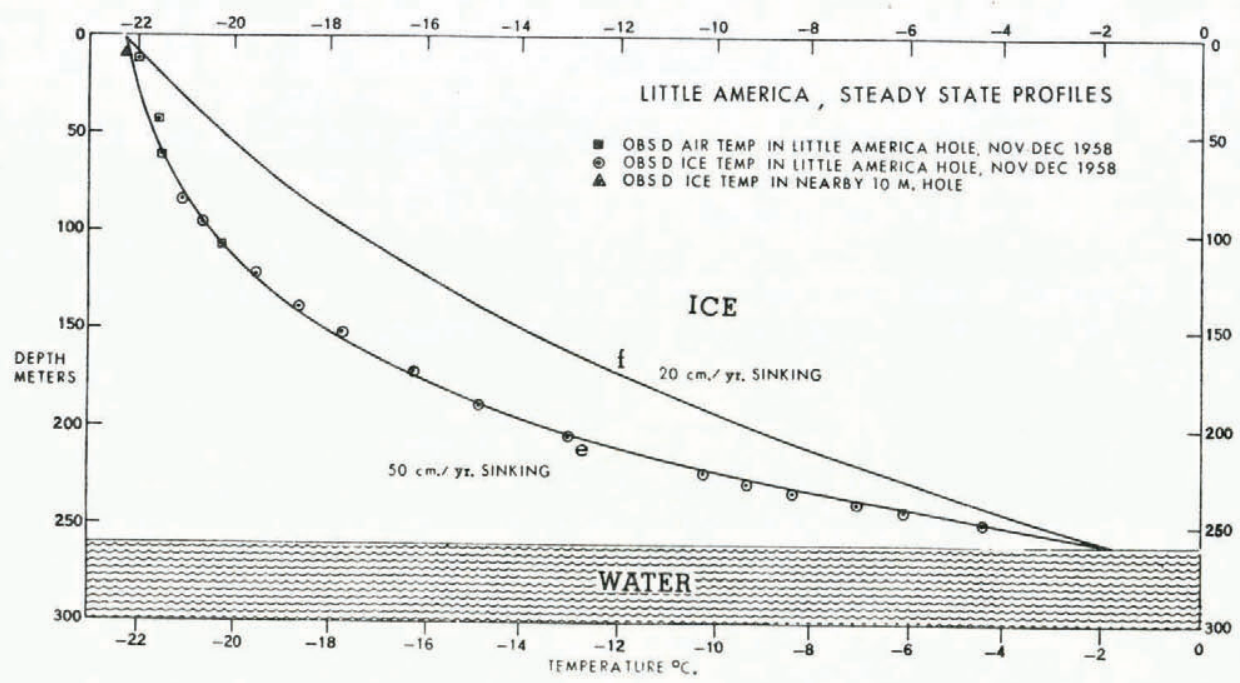

Fig. 3. Little America observed and computed temperatures for steady-state sinking, with constant shelf thickness

2 I $5 \mathrm{~m}$. high radio towers erected in January 1929 , were covered by snow in 30 yr.* Extrapolating Schytt's formula II relating water accumulation to depth ${ }^{8}$ gives an accumulation of about $3^{8 \mathrm{~cm}}$. water equivalent or $4^{\mathrm{I}} \mathrm{cm}$. ice equivalent. But even this higher, probably non-representative, accumulation rate is less than the $50 \mathrm{~cm}$. of ice accumulation which yields the curve of best fit. If the good agreement of curve " $\mathrm{e}$ " is not merely a coincidence but has physical significance, this means that the sinking rate is 2.5 to $\mathrm{I} \cdot 2$ times larger than the annual accumulation, i.e. the shelf is not maintaining constant thickness but is thinning at a rate of 30 to $9 \mathrm{~cm}$. per annum. This can be brought about by a melting rate larger than the annual accumulation or by a horizontal spreading of the ice shelf or both, but each of these processes would violate two of the basic assumptions underlying the above calculations, namely, constant shelf thickness and constant sinking rate of ice through the shelf.

It is important to note that there exists a fundamental difference in assumption between the two models of best fit, " $\mathrm{d}$ " and "e", considered here. For model " $\mathrm{d}$ " the ice is assumed to have originated in isothermal state over land and moved without vertical motion over the ocean $200 \mathrm{yr}$. ago, during which time it lost by melting $120 \mathrm{~m}$. of ice and did not attain a state of thermal equilibrium. For model "e" no earlier land history of the ice need be assumed;

* Because of the original location of Little America I in a shallow snow valley this value is probably too large. 
a steady-state temperature profile exists which agrees remarkably with the observed temperatures provided the sinking rate of the ice layers is $50 \mathrm{~cm}$. per annum, or about 2.5 times the annual accumulation. Because of the difficulty in devising a reasonable physical interpretation of the results of model " $e$ " (despite its nearly perfect agreement with observations) attention will be directed to the results of model " $d$ ".

\section{Energy and Oceanographic Considerations}

The great depth of water ( 300 to $600 \mathrm{~m}$.) beneath the shelf ice at Little America V 9 would permit ample means for water currents to transport heat to the ice bottom. According to Poulter 9 " A current of one to three knots enters Okuma Bay and moves in a south-westerly direction, partly along and partly under the ice at Kainan Bay". Assume that this current is in contact with an average of $100 \mathrm{~km}$. of ice as it passes under the ice shelf from Okuma Bay to Kainan Bay (see Fig. 5). Let us now compute how much energy this current would have to transport in $200 \mathrm{yr}$. to heat to the melting point and melt $120^{\circ} \mathrm{I} \mathrm{m}$. of ice along a strip $\mathrm{I} \mathrm{cm}$. wide and $100 \mathrm{~km}$. long and at the same time heat the remaining ice to the temperatures observed in the Little America hole. The assumptions made are that the ice is initially isothermal at $-22 \cdot 3^{\circ} \mathrm{C}$. and that the Little America ice heating and melting represent typical conditions in that portion of the ice shelf affected by the ocean current.

Energy required to heat $120.1 \mathrm{~m}$. of ice from $-22 \cdot 3^{\circ} \mathrm{C}$. to $-\mathrm{I} \cdot 8^{\circ} \mathrm{C}$.

Energy required to melt $120 \cdot 1 \mathrm{~m}$. of ice

Energy required to heat remaining $259 \mathrm{~m}$. of ice to observed temperature $=113.0 \times 10^{3} \mathrm{cal} . \mathrm{cm} .^{-2}$
$=883.9 \times 10^{3} \mathrm{cal} . \mathrm{cm} .^{-2}$

$$
\begin{aligned}
& =\frac{58.4 \times 10^{3} \mathrm{cal} . \mathrm{cm} .^{-2}}{\text { Total energy }}=1055.3 \times 10^{3} \mathrm{cal} . \mathrm{cm} .^{-2}
\end{aligned}
$$

We shall assume that as the water emerges from under the ice its temperature is at the freezing point. If $\Delta T$ is the initial deviation of the water temperature above its freezing point as the water first comes in contact with the ice bottom, and $\Delta H$ is the thickness of the water layer from which energy is abstracted to heat and melt the ice, then in $200 \mathrm{yr}$. the energy transport by an ocean current of width $\mathrm{I} \mathrm{cm}$. and speed $V \mathrm{~cm}$. sec. ${ }^{-1}$, is $6 \cdot 3^{2} V \Delta T \Delta H \times{ }_{10}^{9} \mathrm{cal}$. This must therefore equal the energy given up to a $\mathrm{I} \mathrm{cm}$. wide strip of ice along the $100 \mathrm{~km}$. current trajectory, $1055 \cdot 3 \times 10^{10} \mathrm{cal}$.

Thus $\Delta T \Delta H=\mathrm{I} \cdot 67 V^{-1} \times \mathrm{IO}^{2}$.

Some pairs of values of $\Delta H$ and $\Delta T$ which satisfy this equation for various values of $V$ are shown in Table II.

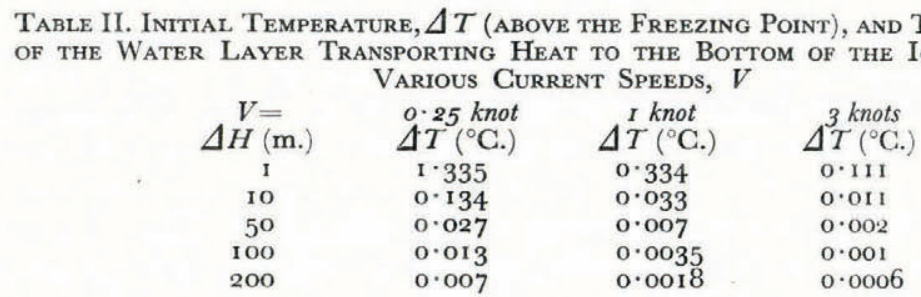

For example, if $50 \mathrm{~m}$. is the thickness of the water layer below the ice which is the principal source of heat for melting and warming the ice above, then its initial temperature departure from the freezing point of sea-water need only be $0.027^{\circ} \mathrm{C}$. for a 0.25 knot current and $0.007^{\circ} \mathrm{C}$. for a $\mathrm{I}$ knot current.

Let us compare the values shown in Table II with observed ocean temperatures in the vicinity of the ice shelf.

Oceanographic soundings made a few kilometers north of the ice shelf at Little America ${ }^{\text {ro, II }}$ revealed temperatures and other data shown in Table III. 
Table III. Oceanographic Soundings near Little Ameriga V (Lat. $78^{\circ}{ }_{11}^{\prime}$ S., LONG. $162^{\circ} 10^{\prime} \mathrm{W}$.)

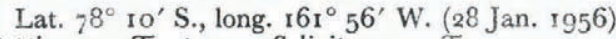

\begin{tabular}{|c|c|c|c|c|c|c|c|c|}
\hline \multicolumn{5}{|c|}{ Lat. $78^{\circ}$ Io' S., long. $\mathrm{I}^{6} \mathrm{I}^{\circ} .56^{\prime}$ W. (28 Jan. 1956) } & \multicolumn{4}{|c|}{ Lat. $78^{\circ}$ 10' S., long. $167^{\circ} 26^{\prime}$ W. (3 Jan. 1957) } \\
\hline $\begin{array}{c}\text { Depth } \\
\text { (m.) }\end{array}$ & $\begin{array}{l}\text { Temp. } \\
\left({ }^{\circ} \mathrm{C} .\right)\end{array}$ & $\begin{array}{c}\text { Salinity } \\
\%\end{array}$ & $\begin{array}{c}T_{f} \\
\left({ }^{\circ} \mathrm{C} .\right)\end{array}$ & $\sigma_{t}$ & $\begin{array}{l}\text { Temp. } \\
\left({ }^{\circ} \mathrm{C} .\right)\end{array}$ & $\begin{array}{c}\text { Salinity } \\
\%\end{array}$ & $\begin{array}{c}T_{f} \\
\left({ }^{\circ} \mathbf{C} .\right)\end{array}$ & $\sigma_{t}$ \\
\hline 0 & -0.50 & $33 \cdot 93$ & $-1 \cdot 85$ & $27 \cdot 29$ & $-1 \cdot 05$ & $33 \cdot 95$ & $-1 \cdot 85$ & $27 \cdot 32$ \\
\hline I0 & -0.50 & 34.01 & $-1 \cdot 86$ & $27 \cdot 35$ & $-1 \cdot 04$ & $34 \cdot 01$ & $-1 \cdot 86$ & $27 \cdot 37$ \\
\hline 20 & -0.68 & $34 \cdot 02$ & $-1 \cdot 86$ & -10 & -0.92 & $34 \cdot 01$ & $-1 \cdot 86$ & $27 \cdot 37$ \\
\hline 30 & $-0 \cdot 84$ & $34 \cdot 02$ & $-1 \cdot 87$ & $27 \cdot 37$ & -0.82 & $34 \cdot 02$ & $-1 \cdot 87$ & $27 \cdot 37$ \\
\hline 50 & $-x \cdot 28$ & $34 \cdot 08$ & $-1 \cdot 90$ & $27 \cdot 44$ & -0.70 & $34 \cdot 05$ & $-x \cdot 90$ & $27 \cdot 39$ \\
\hline 75 & $-1 \cdot 49$ & $34 \cdot 12$ & $-1 \cdot 9^{1}$ & $27 \cdot 48$ & -0.79 & $34 \cdot 07$ & $-1 \cdot 9^{1}$ & $27 \cdot 4 \mathrm{I}$ \\
\hline 100 & $-1 \cdot 66$ & $34 \cdot 15$ & $-1 \cdot 93$ & $27 \cdot 51$ & $-1 \cdot 00$ & $34 \cdot 18$ & $-1 \cdot 93$ & $27 \cdot 5 \mathrm{I}$ \\
\hline 150 & $-1 \cdot 87$ & $34 \cdot 21$ & $-\mathbf{I} \cdot 98$ & $27 \cdot 56$ & $-1 \cdot 72$ & $34 \cdot 33$ & $-1 \cdot 98$ & $27 \cdot 65$ \\
\hline 200 & $-1 \cdot 9 i$ & $34 \cdot 22$ & -2.01 & $27 \cdot 57$ & $-2 \cdot 03$ & $34 \cdot 37$ & $-2 \cdot 0 \mathrm{I}$ & $27 \cdot 69$ \\
\hline 250 & $-1 \cdot 89$ & $34 \cdot 30$ & $-2 \cdot 05$ & $27 \cdot 63$ & $-1 \cdot 88$ & $34 \cdot 39$ & $-2 \cdot 05$ & $27 \cdot 71$ \\
\hline 300 & $-\mathbf{x} \cdot 87$ & $34 \cdot 35$ & $-2 \cdot 09$ & $27 \cdot 67$ & $-1 \cdot 80$ & $34^{\cdot} 4^{\mathrm{I}}$ & $-2 \cdot 09$ & $27 \cdot 72$ \\
\hline $35^{\circ}$ & $-1 \cdot 85$ & $34 \cdot 39$ & $-2 \cdot 12$ & $27 \cdot 70$ & - & & - & - \\
\hline 400 & $-1 \cdot 83$ & $34 \cdot 39$ & $-2 \cdot 16$ & $27 \cdot 70$ & $-\mathbf{x} \cdot 83$ & $34 \cdot 4^{2}$ & $-2 \cdot 16$ & $27 \cdot 73$ \\
\hline 500 & $-1 \cdot 82$ & $34 \cdot 3^{8}$ & $-2 \cdot 23$ & $27 \cdot 70$ & $-1 \cdot 81$ & - & - & - \\
\hline 600 & $-1 \cdot 83$ & $34 \cdot 47$ & $-2 \cdot 3^{I}$ & $27 \cdot 77$ & - & - & - & - \\
\hline 650 & $-1 \cdot 85$ & $34 \cdot 54$ & $-2 \cdot 35$ & $27 \cdot 83$ & - & - & - & - \\
\hline
\end{tabular}

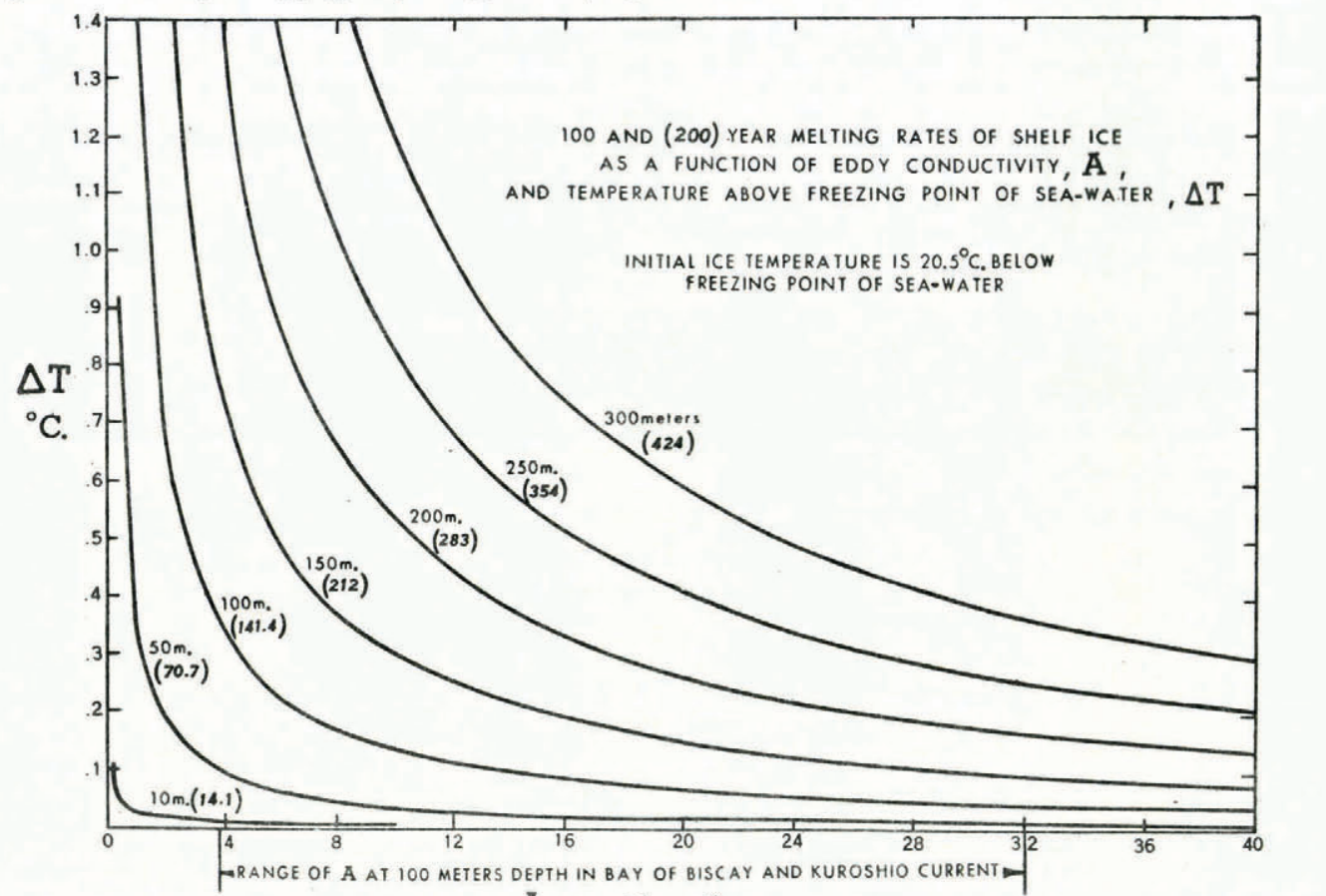

A gm, cm:-1 $\sec ^{-1}$

Fig. 4. 100 and 200 yr. curves of constant ice melt as function of ocean eddy conductivity, A, and temperature of sea-water above its freezing point, $\Delta T$

The values below the horizontal line correspond to depths below the bottom of the ice shelf at Little America V. The water temperatures at these depths are quite close, within a few tenths of the temperature at which sea-water of the observed salinity and pressure begins to freeze, as shown by the figures in the column headed $T_{f}{ }^{12}$

It thus appears unlikely that the temperature of the sea-water under the ice shelf at Little America $\mathrm{V}$ can depart from the freezing point of that sea-water by as much as the $\mathrm{I}^{\circ} \mathrm{C}$. which was assumed in computing the curve of second-best fit, " $d$ ", even if allowance is made for possibly lower salinity and hence higher freezing point. On the other hand curve "c", which was computed on the assumption of $\mathrm{a} \cdot \mathrm{I}^{\circ} \mathrm{C}$. deviation from the freezing point, is only the 
curve of third-best fit (see Table I). Another variable, of course, is the intensity of the mixing processes which transport heat to the bottom of the ice. A low value of $1 \mathrm{~g} . \mathrm{cm} .^{-1} \mathrm{sec} .^{-1}$ was assumed in computing curves "c" and "d". The values may be higher, and it is therefore of some interest to compute melting rates as a function of eddy conductivity, $A$, and temperature above the freezing point of sea-water, $\Delta T$. This can be done by means of equation (14) given in Appendix B. The results for an ice shelf, initially isothermal at $20.5^{\circ} \mathrm{C}$. below the freezing point of sea-water, are shown in Fig. 4 for both 100 and 200 yr. melting (the latter melting rates are the numbers in parentheses).

As expected the curves of equal melt are hyperbolic in appearance. It is seen that at a given $\Delta T$, the melting rate increases slower than $A$. Thus for $\Delta T=0.2^{\circ} \mathrm{C}$. and $A=2$, the $100 \mathrm{yr}$. melt is $50 \mathrm{~m}$.; for $A=\mathrm{r} 6$, it is $150 \mathrm{~m}$. An inspection of Fig. 4 reveals that for a given $\Delta T$ the melting rate is approximately proportional to $\sqrt{ } A$.

Returning to the problem of the ice shelf melt it is seen from Fig. 4 that one can achieve compatibility of the second-best fit curve " $\mathrm{d}$ " and its $120 \mathrm{~m}$. of melt with a $\Delta T=0 \cdot 1^{\circ} \mathrm{C}$. instead of $\mathrm{I}^{\circ} \mathrm{C}$., by increasing the eddy conductivity, $A$, from $\mathrm{I}$ to about $\mathrm{Io}$. (As explained in Appendix B, the temperature distribution in the ice and water will remain the same so long as one selects pairs of values, $\Delta T$ and $A$, from the same curve of constant melt.) Since data on $\Delta T$ and $A$ under the Ross Ice Shelf are not available, ${ }^{*}$ it does not appear possible to arrive at an unambiguous estimate of the time of duration over water and melting rate of the ice shelf at Little America V. Nevertheless, it appears worth while to carry out an exercise using the results of the computation which led to second-best fit curve "d", and I $20 \mathrm{~m}$. of bottom melting in $200 \mathrm{yr}$., to see if this result is compatible with observations of the speed and direction of motion of the ice shelf near Little America.

\section{Observed Motions of the Ige Shelf near Little America V}

In trying to obtain motions of the Ross Ice Shelf in the neighbourhood of Little America V, use has been made of old and new positions of certain ice shelf features such as Framheim (Amundsen's IgI I-I2 camp), Kainan Bay, the site of Little America I and the site of Little America III (Fig. 5).

The data are summarized in Table IV.

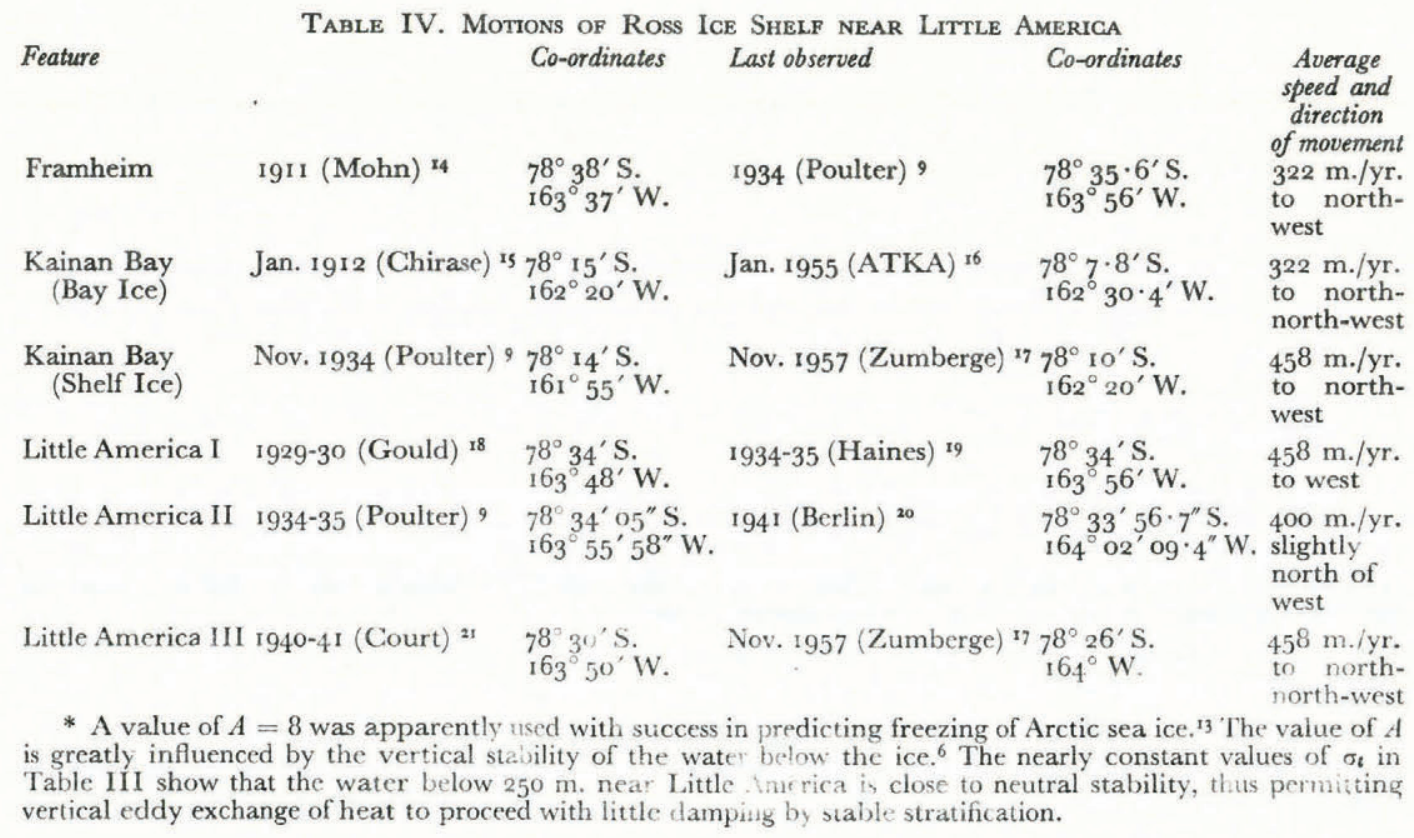




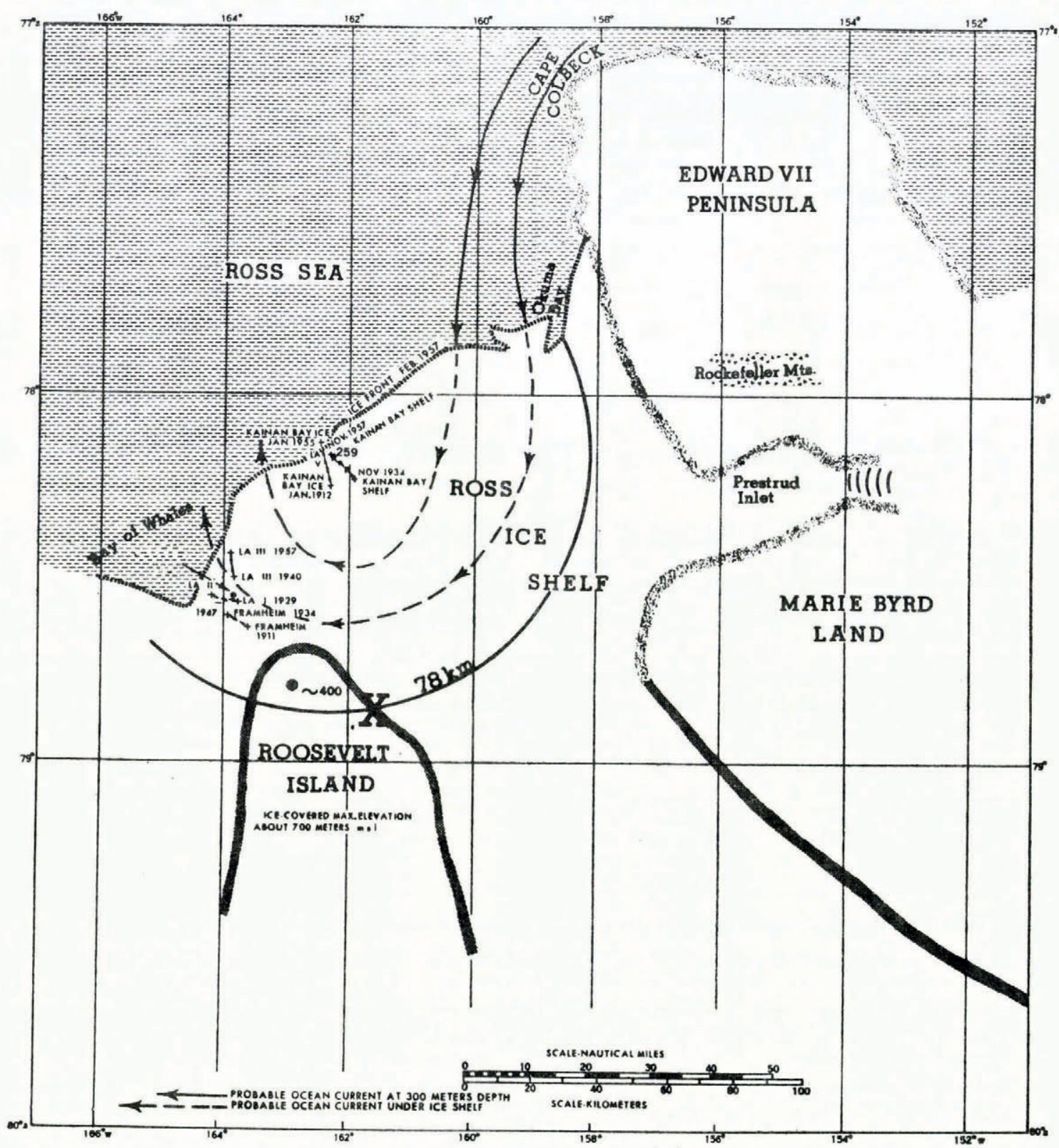

Fig. 5. Eastern portion of Ross Ice Shelf. Large numerals refer to ice thickness in meters at Little America V and northerm tip
of Roosevelt Island

There is surprisingly good agreement in the absolute motions of the ice shelf taken at various places $60 \mathrm{~km}$. apart. Although each station has a component of motion westward, there are differences in direction. Taking the average of the two values near Kainan Bay, Little America V appears to have moved north-north-west or north-west at $390 \mathrm{~m}$./yr.*

* This is to be compared with a motion of $455 \mathrm{~m}$./yr. to the north-north-east observed at the western end of the Ross Ice Shelf using Scott's 1902 depot as a marker. ${ }^{22}$ 
The direction of motion appears to be reasonable if it is interpreted to be along a vector resultant of nearby Roosevelt Island ice cap moving northward and the inland ice of the more distant Marie Byrd Land moving westward towards Roosevelt Island whence it is deflected north-westward or north-north-westward.

Assuming that the motion of $390 \mathrm{~m}$./yr. obtained over the past $200 \mathrm{yr}$., which is the period of time Little America V ice is presumed to have been in contact with the ocean, we shall try to find its position in $175^{8}$. This would be somewhere on an arc of $78 \mathrm{~km}$. radius with Little America $\mathrm{V}$ as the center as shown in Fig. 5.

Suppose the ice is moving to the north-north-west, then $200 \mathrm{yr}$. ago it would have been at the intersection X (Fig. 5) of the $78 \mathrm{~km}$. arc and the north-eastern coast of Roosevelt Island where the present ice thickness is presumably near $400 \mathrm{~m}$.; this could have been the thickness 200 yr. ago.* If this were so, then $400-259=14 \mathrm{I} \mathrm{m} .+40 \mathrm{~m}$. of water equivalent of accumulated snow, or a total of $18 \mathrm{I} \mathrm{m}$., would have had to be lost during the $200 \mathrm{yr}$. journey of the ice to Little America $V$ where the present ice thickness is $259 \mathrm{~m}$. If all this loss of vertical thickness of $\mathrm{I} 8 \mathrm{I} \mathrm{m}$. were caused by melting then by interpolation between the $200 \mathrm{yr}$. ( $14 \mathrm{I} \cdot 4 \mathrm{~m}$.) and $(2 \mathrm{I} 2 \mathrm{~m}$.) curves in Fig. 4, it is seen that this melting could occur with fairly large values of $\Delta T$, compared to those shown in Table III, or with fairly large values of $A$, compared to the range shown at the bottom of Fig. 4-neither of which are likely possibilities.

It thus appears that the thinning of the ice shelf as it moves $78 \mathrm{~km}$. from a presumed point $\mathrm{X}$ (Fig. 5) to Little America V could not have all been caused by melting from below and that a horizontal spreading of the ice probably plays an important rôle. Since the channel between Marie Byrd Land and Roosevelt Island widens appreciably north of lat. $79^{\circ} \mathrm{S}$. (see Fig. 5), this should encourage horizontal spreading. A lateral spreading of the ice by only i 6 per cent, in moving from point $\mathrm{X}$ to Little America with uniform speed seaward throughout, could account for the thinning from $440 \mathrm{~m}$. of ice at point $\mathrm{X}(440=400$ observed +40 accumulated in $200 \mathrm{yr}$.) to $379 \mathrm{~m}$. at LAS V $(379=259$ observed + 120 melted $)$. If the speed of the ice seaward increases near the edge of the ice as observed at Maudheim ${ }^{24}$ this would also contribute to the thinning of the ice. Of course, the nearer to the sea the more rapid should also be the melting but, as stated above, it would hardly seem possible to explain by melting alone the loss of $18 \mathrm{r}$ m. of ice in the presumed $200 \mathrm{yr}$. of motion from point X to Little America.

\section{The Maudheim Is-ShelF}

The availability of temperatures to a depth of $100 \mathrm{~m}$. in the Maudheim Is-shelf ${ }^{23}$ permits another case to be examined under conditions different from those of Little America. At Maudheim (lat. $71^{\circ} 03^{\prime}$ S., long. $1^{\circ} 56^{\prime}$ W.; $3^{8} \mathrm{~m}$. a.s.l.), the average annual temperature in the top $7 \mathrm{~m}$. of the snow is $-17.4^{\circ} \mathrm{C}$. instead of $-22.3^{\circ} \mathrm{C}$. at Little America, the accumulation is close to $40 \mathrm{~cm}$. of water instead of $20 \mathrm{~cm}$. and the shelf thickness is close to $200 \mathrm{~m}$. instead of $259 \mathrm{~m}$. Although the temperatures were measured only to a depth of roo m., Schytt extrapolated the profile to the sea-water freezing point at the bottom of the ice shelf, which in 1954 he estimated was $185 \mathrm{~m}$. thick.

In Fig. 6 are plotted Schytt's observed and extrapolated temperatures for the Maudheim Is-shelf. The writer is indebted to Dr. Schytt for furnishing him in advance of publication the numerical values of the observed temperatures, a smoothed curve of which was published in 1954; the extrapolated values were scaled from Schytt's extension of this curve. ${ }^{23}$ In the following computations the writer used a bottom temperature of $-\mathrm{I} \cdot 8^{\circ} \mathrm{C}$, , a surface temperature of $-17.4^{\circ} \mathrm{C}$. and a thickness of $185 \mathrm{~m} . \dagger$

Three curves are drawn in Fig. 6. The first, curve "a", is copied from curve (2) of Robin's

* The assumption made here is that the ice shelf remains essentially unchanged in 200 yr., that icebergs break off periodically and restore the ice shelf to its original area and shape.

$\uparrow$ The thickness is now estimated to have been close to $200 \mathrm{~m}^{24}$ 
Fig. $4^{5}$ which was drawn on the assumption of bottnm melting equal to accumulation in a steady-state model, where the downward velocity of the ice is equal to the annual accumulation and thus the bottom melt rate. Although Robin gives no figure for the ice accumulation value he used in deriving his curve, presumably he took the Maudheim value of $40 \mathrm{~cm} . \mathrm{yr}^{-1}$. This curve departs widely from the observed and extrapolated temperatures.

In Fig. 6 is another curve, "b", based on the same steady-state model, but using a $109 \mathrm{~cm}$. yr. ${ }^{-1}$ ice accumulation; this curve fits the observed and extrapolated temperatures quite well. Curve "c" is a non-steady-state solution resulting from the residence for $75 \mathrm{yr}$. of an ice sheet, initially isothermal at $-17 \cdot 4^{\circ} \mathrm{C}$., over an ocean whose deep water temperature under the ice shelf is taken as $-0.8^{\circ} \mathrm{C}$. and whose eddy conductivity coefficient, $A$, equals unity. In $75 \mathrm{yr} .75 \mathrm{~m}$. of ice are melted. Curves for $50 \mathrm{yr}$. (6I I I m. melt) and for $100 \mathrm{yr}$. (86.5 m. melt), not shown here, depart more widely from the observed temperature than the $75 \mathrm{yr}$. curve.

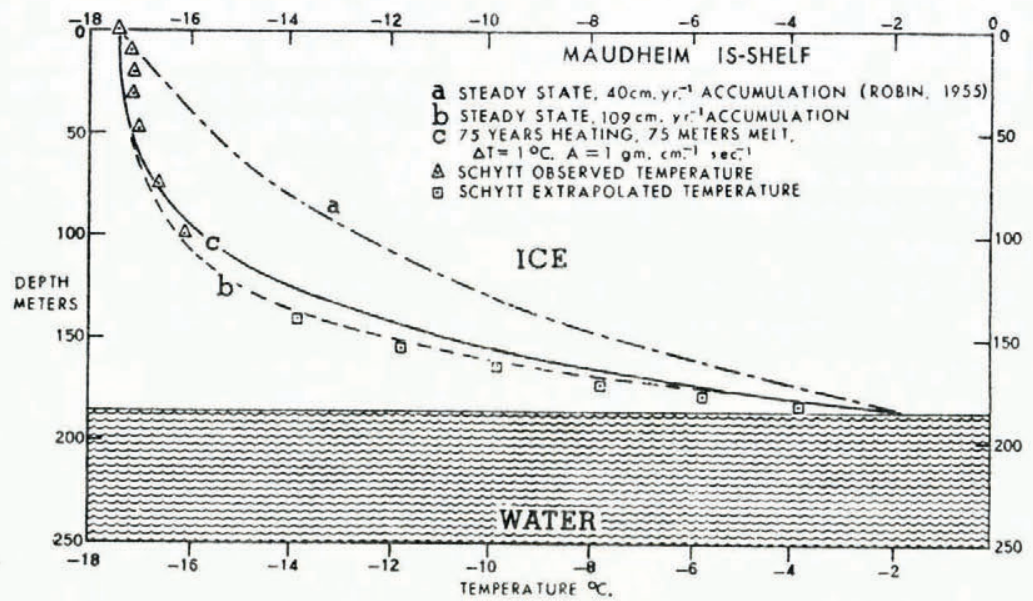

Fig. 6. Maudheim observed and computed temperatures. Curves " $a$ " and " $b$ " are for steady-state accumulation (sinking) with constant shelf thickness. Curve " $c$ " is for $75 y$ r. of heating and melting

Here again, as in the case of Little America, the curve of best-fit is a steady-state model wherein the sinking speed of the ice, $\operatorname{I0g} \mathrm{cm} . \mathrm{yr}^{-1}$, is more than double the annual accumulation, $40 \mathrm{~cm} . \mathrm{yr}^{-1}$.

Again, taking into account the assumptions underlying this particular steady-state model, a physical interpretation is difficult. Therefore, once again, we pursue the consequences of the non-steady-state heating and melting model whose $75 \mathrm{yr}$. curve, "c", is associated with $75 \mathrm{~m}$. of melted ice. As in the case of the Little America hole, let us back-track the Maudheim hole to where it might have been $75 \mathrm{yr}$. before 1950 .

Swithinbank ${ }^{24}$ has estimated the average movement of the Maudheim Is-shelf across the $36 \mathrm{~km}$. width of its discharge channel to be $280 \mathrm{~m}$. $/ \mathrm{yr}$. In $75 \mathrm{yr}$., if the speed of motion remained the same, the ice would have been somewhere on an arc of $21 \mathrm{~km}$. radius from Maudheim. The only direction where ice $21 \mathrm{~km}$. from Maudheim is on land instead of ocean is due east, on the coast of Hill A (see Fig. 2, Swithinbank ${ }^{24}$ ). If the Maudheim ice had been originally at this spot and had the same thickness there as now it would have been somewhere between 309 and $420 \mathrm{~m}$. thick; these are the respective thicknesses of the two seismic stations straddling the hypothetical point: the first, Station 40 , is on the ice shelf and the second, Station I 75, is on Hill A. ${ }^{25}$ If we take an average value, then the thickness of the ice now at Maudheim could have been $365 \mathrm{~m}$. $75 \mathrm{yr}$. ago. Thus the decrease from $395(365 \mathrm{~m}$. initially plus $30 \mathrm{~m}$. accumulation in $75 \mathrm{yr}$.) to $275 \mathrm{~m}$. (200 m. thick now plus $75 \mathrm{~m}$. melt) 
equals $120 \mathrm{~m}$., which would have to be accounted for by horizontal spreading and vertical shrinking. A horizontal spreading of 43 per cent in the $75 \mathrm{yr}$. of motion could account for the observed thinning. Swithinbank's largest area increase in 6 months, 0.176 per cent, was measured for a small triangular area directly east of Maudheim. In $75 \mathrm{yr}$. this would equal 30 per cent, too small to account for the observed thinning. If the initial ice thickness had been that of the closest observed shelf thickness, $309 \mathrm{~m}$. at Station 40 , located $3.7 \mathrm{~km}$. south-west of the hypothetical point, the divergence in $75 \mathrm{yr}$. need only have been 23 per cent, in fair agreement with Swithinbank's measurement cited above.

This "exercise" is, of course, interesting but not very conclusive, since it is based on the results of one particular theoretical model and an assumed direction of motion from the nearest grounded ice area (Hill A). From geographical considerations Swithinbank estimated the direction of motion of the Maudheim Is-shelf to be slightly west of north as compared to the due west direction assumed in the above computations.

Because of an apparent discontinuity at $70 \mathrm{~m}$. in the vertical profile of ice crystal area in the Maudheim hole, Schytt speculated that this represented a change from local (shelf) accumulation to the original inland ice. ${ }^{8}$ Since it would take $140 \mathrm{yr}$. to lay down $70 \mathrm{~m}$. of ice, Schytt believed it took $140 \mathrm{yr}$. for the ice to travel from the $650 \mathrm{~m}$. high ridge $45 \mathrm{~km}$. to the south-east of Maudheim, or an average rate of movement of $320( \pm 80) \mathrm{m}$. per annum to the north-west. This compares with Swithinbank's speed of $280 \mathrm{~m}$. per annum in a direction slightly west of north. ${ }^{24}$

According to Fig. 6, Schytt's estimate of I40 yr. for time of passage of the Maudheim Is-shelf over the ocean would yield temperatures too high in the layer 50 to $100 \mathrm{~m}$. depth; the observed temperatures are colder than the roo yr. heating curve and of course would be even colder than the $140 \mathrm{yr}$. curve. But it should be pointed out that for shallow profiles such as Maudheim's, where most of the temperature measurements are made in ice laid down by accumulation in transit, it is difficult to analyse the thermal history of the entire thickness of the ice shelf. For example, if the inland ice had initially a temperature several degrees lower than the $-17 \cdot 4^{\circ} \mathrm{C}$. assumed here, which seems likely, then those temperatures near the bottom of the Maudheim hole are not necessarily incompatible with a I $40 \mathrm{yr}$. residence time over the ocean (see Fig. 9).

\section{The Ice Shelf at the Ellsworth I.G.Y. Station}

At the Ellsworth I.G.Y. station (lat. $77^{\circ} 43^{\prime}$ S., long. $41^{\circ} 08^{\prime}$ W.; $4^{I} \mathrm{~m}$. a.s.l.) a deep pit was dug to a depth of $31.3 \mathrm{~m}$., and a $10 \mathrm{~cm}$. hole was drilled in the pit floor to a depth of $56.91 \mathrm{~m} .{ }^{26}$ The pit and hole were located in a north-south oriented trough in the ice shelf $150 \mathrm{~m}$. east of the station and $3.5 \mathrm{~m}$. below the station elevation. Temperatures in the pit were obtained by inserting a thermohm $3 \mathrm{~m}$. into the pit wall at each depth; temperatures in the drill hole were obtained by placing a thermohm at the bottom of the drill hole at the end of each day's drilling (Table V). The depth at $0.0 \mathrm{~m}$. is the average annual air temperature as measured in the meteorological shelter at the camp site.

The temperatures are plotted in Fig. 7 and show decreasing temperatures from the surface, $-23 \cdot 1^{\circ} \mathrm{C}$. to $-26 \cdot 7^{\circ} \mathrm{C}$. at $43.9^{1} \mathrm{~m}$., a minimum of $-26 \cdot 74^{\circ} \mathrm{C}$. at $54.74 \mathrm{~m}$. and finally what appears to be a slight increase to $-26 \cdot 72^{\circ} \mathrm{C}$. at $56.91 \mathrm{~m}$., the bottom of the hole. This decreasing temperature with depth at Ellsworth station differs from Little America and Maudheim, where the temperatures increase slowly with depth in the top $57 \mathrm{~m}$. (see Figs. I and 6).

It would appear that that portion of Filchner Ice Shelf near Ellsworth station differs significantly in thermal history from the ice shelves at Little America and Maudheim. It is tempting to consider that the Ellsworth ice is being heated from above by a warmer atmospheric environment (including accumulation) as well as from below by the warm ocean under the ice shelf which is $232 \mathrm{~m}$. thick and is floating on an ocean $79^{2} \mathrm{~m}$. deep. ${ }^{27}$ 
Table V. Ellsworth Station Deep Pit Temperatures, $1957^{26}$

Thermohm element placed $3 \mathrm{~m}$. into pit wall at each depth

\section{Vertical depth}

(m.)

$0 \cdot 00$

$4 \cdot 35$
$9 \cdot 66$

$9 \cdot 66$
$14 \cdot 49$

14.49
$19 \cdot 32$

$24 \cdot 15$
$28 \cdot 98$
Temp.

( $\left.{ }^{\circ} \mathrm{C}.\right)$

$-23 \cdot 10$ (average air temp.)

$-24 \cdot 05$

$-24 \cdot 20$

$-25 \cdot 15$

$-25 \cdot 75$

$-26 \cdot 05$

$-26 \cdot 30$

Thermohm placed on bottom of core hole at end of each day's drilling Vertical depth

(m.)

$36 \cdot 22$

$4 \mathrm{I} \cdot \mathrm{I} 5$

$43 \cdot 91$

$46 \cdot 07$

$46 \cdot 77$

$54 \cdot 74$

$56 \cdot 9$ I

Temp.

( ${ }^{\circ} \mathrm{C}$.)

$-26 \cdot 50$

$-26 \cdot 65$

$-26 \cdot 70$

$-26 \cdot 70$

$-26 \cdot 70$

$-26 \cdot 74$

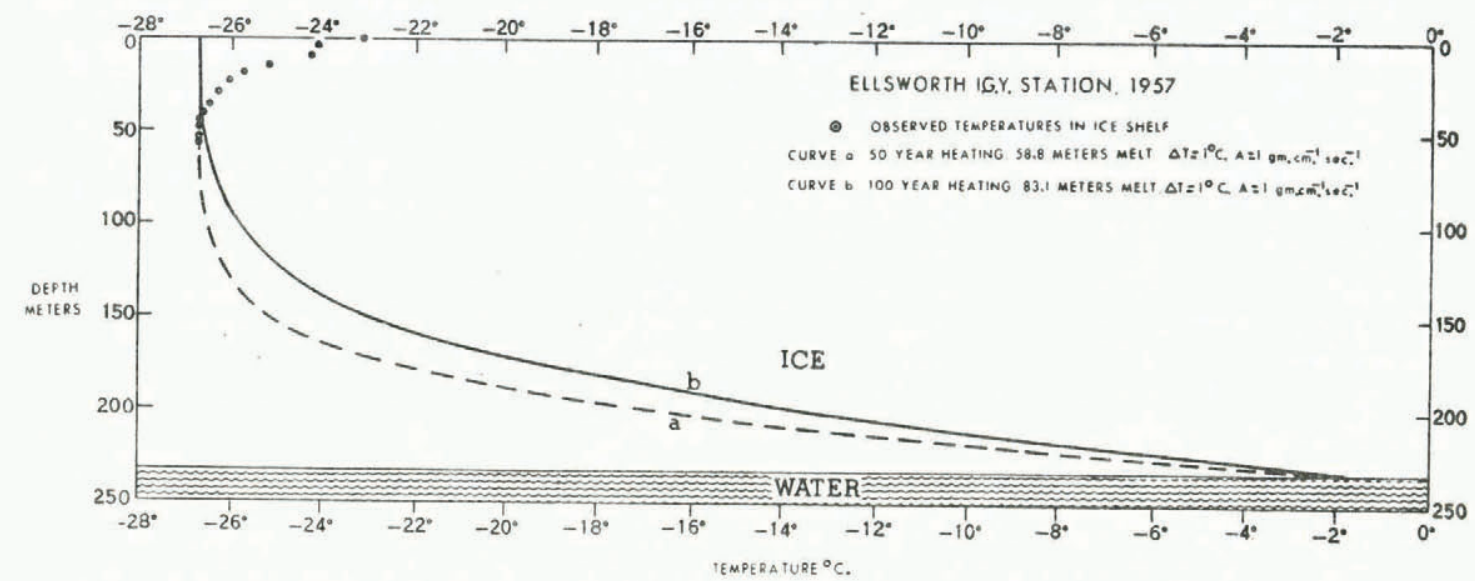

Fig. 7. Ellsworth observed and computed temperatures, heating and melting

Let us assume a model having these properties: an ice shelf, initially isothermal at $-26 \cdot 74^{\circ} \mathrm{C}$., the minimum temperature in the Ellsworth hole, moves from land and floats on an ocean, whose deep temperature is $-0.8^{\circ} \mathrm{C}$., or $\mathrm{I}^{\circ} \mathrm{C}$. above the freezing point of sea-water. Using the theory outlined in Appendix B we construct two temperature profiles: "a", for 50 yr. residence time, during which $58.8 \mathrm{~m}$. of ice are melted, and "b", for roo yr. residence time, during which $83.1 \mathrm{~m}$. of ice are melted (Fig. 7). In both cases the eddy conductivity of the ocean beneath the ice shelf was assumed to be $A=\mathrm{I} \mathrm{g.} \mathrm{cm}^{-1} \mathrm{sec}^{-1}$ and the effect of sinking of ice was neglected.

In comparing the observed temperatures with the theoretical curves it is seen that curve "b", the roo yr. curve, is slightly warmer than the observed points from 57 to $47 \mathrm{~m}$., but that these latter points fall on the $50 \mathrm{yr}$. curve which, indeed, is isothermal from about $90 \mathrm{~m}$. to the surface.

In attempting to base an estimate of age on the observed points it is critical to know 
whether the observed temperatures below 4I m. are truly isothermal or decrease to a slight minimum and begin to increase. Since we are dealing with temperatures in the second decimal place we cannot say with certainty whether additional points would follow the 50 yr. curve or perhaps a $75 \mathrm{yr}$. ( $72 \mathrm{~m}$. melt) curve. We shall assume the latter curve to be the correct one and attempt to follow through the consequences.

The nearest (ice-covered) land areas from Ellsworth station are Coats Land, $122 \mathrm{~km}$. to the east, and a large island the same distance to the west. Southward along the ice shelf between these two land masses the Ellsworth traverse made its way during the $1957-5^{8}$ season (Fig. 8). Temperatures observed at $9 \mathrm{~m}$. depths at various stations on this traverse are plotted in Fig. 8. ${ }^{26}$ The temperatures decrease southward, reaching a minimum of $-28 \cdot 39^{\circ} \mathrm{C}$. at Station 5 , in the ice shelf $175 \mathrm{~km}$. south of Ellsworth station. The $9 \mathrm{~m}$. temperature then rises to a maximum of $-24.03^{\circ} \mathrm{C}$. at Station 7 on the large unnamed island and drops again to $-26 \cdot 39^{\circ} \mathrm{C}$. and $-27.37^{\circ} \mathrm{C}$. at the next two stations on the ice-covered island.

Because of the greater out-pouring of glaciers (e.g. Slessor Glacier) from the elevated Coats Land we assume that the ice at Ellsworth has come from that portion of Coats Land closest $(55 \mathrm{~km}$.) to Station 4, or a distance of $155 \mathrm{~km}$. to the south-east of Ellsworth station. If the ice, after moving to the ocean at that point, had remained over water for $75 \mathrm{yr}$. while moving to Ellsworth station, this would mean a speed of $2 \mathrm{~km}$. yr. ${ }^{-1}$, as compared to $0.39 \mathrm{~km}$. yr. ${ }^{-1}$ for Little America and $0.28 \mathrm{~km} . \mathrm{yr}^{-1}$ for Maudheim.*

During this rapid movement north-westward for $75 \mathrm{yr}$., the ice would not only heat from below as indicated in Fig. 7, but would heat from above, both by a warmer atmosphere and accumulation of snow of higher temperature. Let us look at the upper portion of the Ellsworth temperature profile assuming that initially it was isothermal at $-26 \cdot 74^{\circ} \mathrm{C}$. and in $75 \mathrm{yr}$. moved $155 \mathrm{~km}$. to the present location of Ellsworth station whose $9 \mathrm{~m}$. temperature is $-24 \cdot 2^{\circ} \mathrm{C}$. Since the annual accumulation at the station is about $20 \mathrm{~cm}$. water equivalent, ${ }^{28}$ in $75 \mathrm{yr}$. this would amount to $15 \mathrm{~m}$.

Application of Schytt's formula, ${ }^{8}$ associating water equivalent accumulation ( $15 \mathrm{~m}$.) and depth of accumulation, yields a depth of $26 \mathrm{~m}$. which is close to the depth in the Ellsworth hole at which the temperature becomes practically constant (Table V). It thus appears that the upper warm layer of the Ellsworth ice represents snow which accumulated as the ice moved rapidly $\left(\sim 2 \mathrm{~km} . \mathrm{yr}^{-\mathrm{r}}\right)$ towards the north-west.

\section{Shelf Heating from Above and Below}

It is likely that the Ellsworth temperature profile represents an early stage of the Little America ice after it started on its journey from the presumed point $\mathrm{X}$ to Little America $\mathrm{V}$ (see Fig. 5). Although the temperature gradient on the Ellsworth trail ${ }^{26}$ is only 0.4 that of the Little America gradient 4 the Ellsworth ice is apparently moving 5 times faster, thus cutting across isotherms at twice the speed of the Little America ice. This is probably the reason why no sign of the minimum temperature is found in the Little America hole.

The process of warming up a moving ice shelf both from below and above is illustrated schematically in Fig. 9 where the ice shelf is assumed to maintain constant thickness.

The curve for time "o", when the ice leaves the land for the sea, is assumed to be isothermal at the average temperature of the land area where the ice was laid down (practically all of geothermal heat influx will be transmitted throughout the thin ice during its initial years of growth so that its temperature will be nearly isothermal ${ }^{29}$ ).

After time " $I$ " in the journey of the ice to a warmer region, curve " $I$ " shows the influence

* At the I.G.Y. Antarctic Symposium of Buenos Aires, 17-25 November 1959, Dr. C. A. Lisignoli and Dr. C. O. Mejías of the Instituto Antártico Argentino reported that, from astronomical fixes, the portion of the Filchner Ice Shelf from General Belgrano station (located $50 \mathrm{~km}$. east of Ellsworth) eastward nearly to the Moltke Nunataks is moving northward at approximately $1,300 \mathrm{~m}$. yr. ${ }^{-1}$. No determination was made of the east-west component of the motion. 


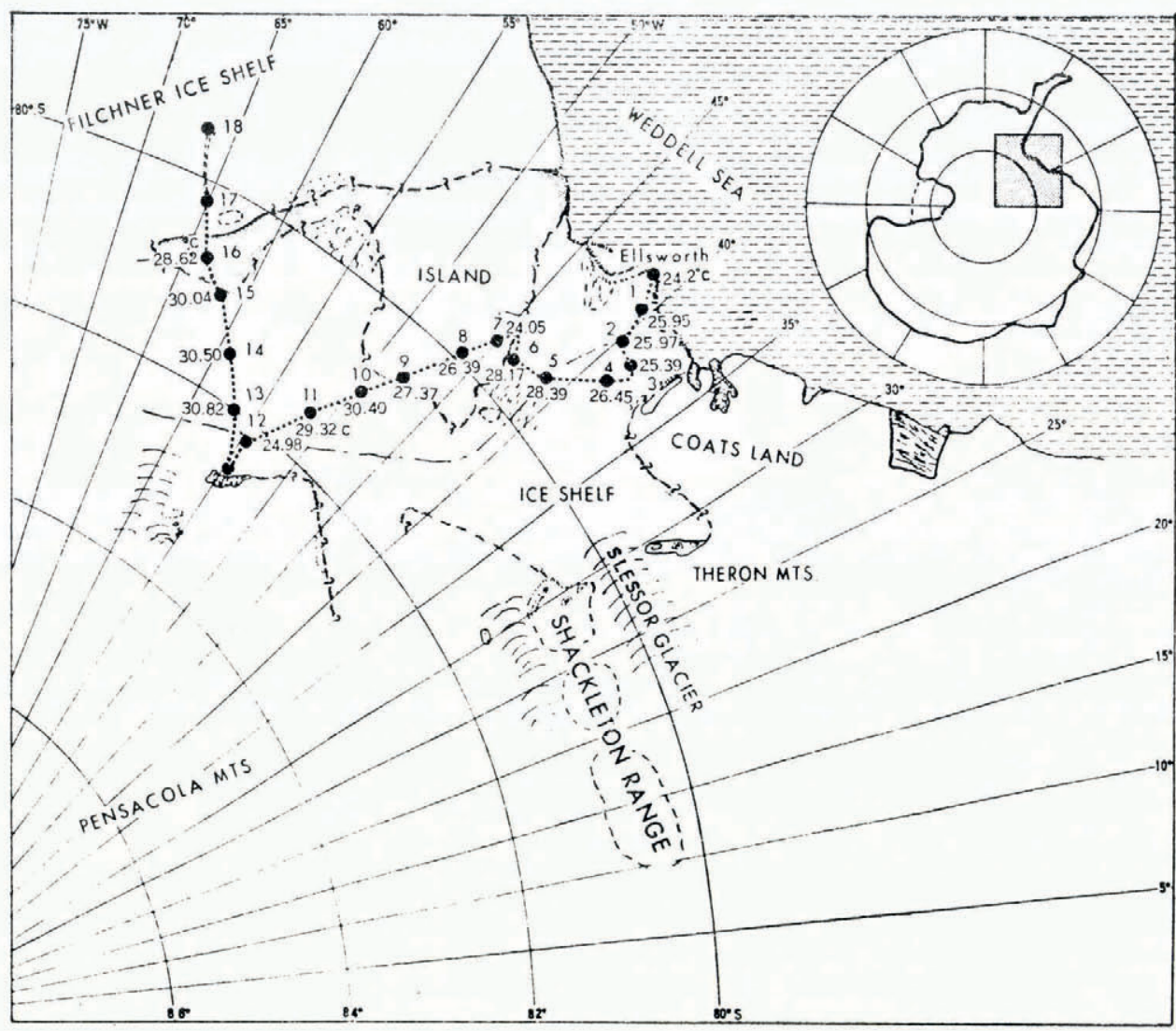

Fig. 8. Eastern portion of Filchner Ice Shelf. $9 \mathrm{~m}$. snow temperatures are given in minus degrees Celsius. (Adapted from map E-I, Augenbaugh, Neuberg and Walker) ${ }^{26}$

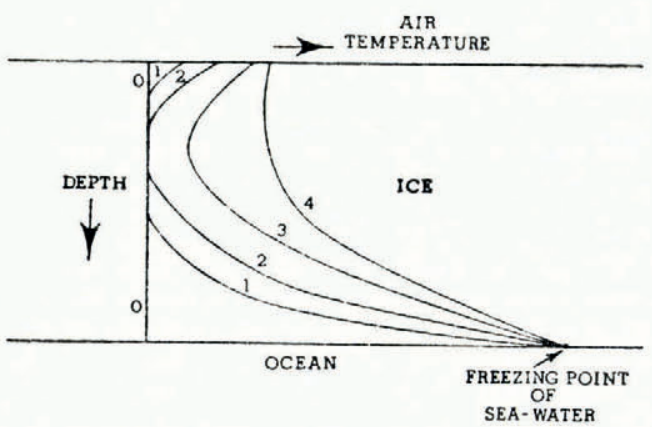

Fig. 9. Warming of an initially isothermal ice shelf from above and below (schematic)

of both oceanic heating and a warmer atmospheric environment. At time " 2 " the process continues, while at time " 3 " a curve similar to the Ellsworth profile emerges. After time " 4 " a curve is found similar to those for Little America and Maudheim.

It thus appears as if a more realistic theoretical model must be constructed whereby the combined effects of heating from below and above should be taken into account, together with effects of sinking of the ice layers. The mathematical aspects of such a combined model 
would be formidable and it would be helpful if deep temperature profiles could be obtained "up-stream" from such places on an ice shelf as Little America, Maudheim and Ellsworth.

\section{Acknowledgements}

It is a pleasure to acknowledge the helpful comments by Dr. Gordon de Q. Robin who reviewed the original manuscript and detected a numerical error in the Maudheim steadystate solution.

MS received 22 May 1959 and in revised form 24 September 1959

\section{REFERENGES}

I. Ragle, R. H., Hansen, B. L., Gow, A. J., and Patenaude, R. W. Post operational report-Antarctic drillingI 958-59 season. Part I. Core and drill hole investigations. Part II. Drilling operations. I.G.Y. Glaciological Report Series (New York, I.G.Y. World Data Center A, Glaciology, American Geographical Society). [In the press.]

2. Gould, L. M. Antarctic prospect. Geographical Review, Vol. 47, No. 1, 1957, p. 28.

3. Zumberge, J. H. Private communication, November 1957.

4. Crary, A. P. Private communication, May 1959.

5. Robin, G. de Q. Some factors affecting the temperature distribution in large ice sheets. Union Geodesique et Géophysique Internationale, Association Internationale d'Hydrologie Scientifique, Assemblée Générale de Rome 1954, Tom. 4, [1956], p. 411-20. [A more complete account is published in fournal of Glaciology, Vol. 2, No. 18, 1955, p. 523-32.]

6. Sverdrup, H., and others. The oceans. New York, Prentice-Hall, 1942, p. 136-37, 476-77.

7. Benfield, A. E. The temperature in an accumulating snowfield. Monthly Notices of the Royal Astronomical Society, Geophysical Supplement, Vol. 6, No. 3, 1951, p. 139-47.

8. Schytt, V. Glaciology. II. Norwegian-British-Swedish Antarctic Expedition, 1949-52. Scientific Results, Vol. 4, A, B, C, 1958 .

9. Poulter, T. C. Seismic measurements on the Ross Shelf Ice. Transactions. American Geophysical Union, Vol. 28, No. 2, 1947, p. 162-70; No. 3, 1947, p. 367-84. [Also published later in Geophysical studies in the Antarctic. Stanford, Calif., Stanford Research Institute, [1950].]

10. Anonymous. Report on Operation Deepfreeze I. Washington, D.C., U.S. Hydrographic Office, 1956, p. D-7. (H.O. 1633I-I.)

II. Anonymous. Operation Deepfreeze II, 1956-57. Oceanographic survey results. Washington, D.C., U.S. Hydrographic Office, 1957, p. 73.

12. Thompson, T. D. Physical properties of sea water. Bulletin of the [U.S.] National Research Council, No. 85, 1932, p. 63-94. (Physics of the Earth, Vol. 5. Oceanography.)

13. Callaway, E. B. An analysis of environmental factors affecting ice growth. Washington, D.C., U.S. Hydrographic Office, 1954. (Technical Report TR-7.)

14. Mohn, H. Roald Amundsen's Antarctic Expedition, scientific results: meteorology. Skrifter udg. af Videnskabsselskabet $i$ Christiania. I. Math. nat. Kl., I915, No. 4, p. 38-72.

15. Chirase, N. Nankyokuki. [Report of the Japanese Antarctic Expedition, 1910-12, pub. December 1913.] [Translation appears serially in Antarctic record. Report of Japanese Antarctic Research Expedition. Tokyo, Ministry of Education [reference on position of Kainan Bay appears on p. 62 of Vol. 4, 1958].]

16. Anonymous. Report of U.S. Antarctic expedition, 1954-55, conducted by USS Atka (AGB-3). 1955, p. 02-1.

17. Zumberge, J. H. Preliminary report on the Ross Ice Shelf deformation project. I.G.Y. Glaciological Report Series (New York, I.G.Y. World Data Center A, Glaciology, American Geographical Society), No. I, 1958.

18. Gould, L. M. The Ross Ice Shelf. Bulletin of the Geological Society of America, Vol. 46, 1935, p. I367-94.

19. Haines, W. C. Meteorological results of the Byrd Antarctic Expeditions 1928-30, 1933-35. Monthly Weather Review, Supplement, No. 41, 1939.

20. Berlin, L. M. Ground surveys accomplished at West Base, Antarctica. Proceedings of the American Philosophical Society, Vol. 89 , No. 1, 1945, p. 386.

21. Court, A. Meteorological data for Little America III. Monthly Weather Review, Supplement, No. 48, r949.

22. Debenham, F. The problem of the great Ross Barrier. Geographical fournal, Vol. 11 2, Nos. 4-6, $194^{8}$, p. $196-218$.

23. Schytt, V. Glaciology in Queen Maud Land. Geographical Review, Vol. 44, No. 1, 1954, p. 70-87.

24. Swithinbank, C. W. M. Glaciology. I. The movement of the ice shelf at Maudheim. Norwegian-BritishSwedish Antarctic Expedition, 1949-52. Scientific Results, Vol. 3, C, 1958.

25. Robin, G. de Q. Glaciology. III. Seismic shooting and related investigations. Norwegian-British-Swedish Antarctic Expedition, 1949-52. Scientific Results, Vol. 5, 1958.

26. Augenbaugh, N., Neuberg, H., and Walker, P. U.S.N.C.-I.G.Y. Antarctic glaciology data, field work 1957 and $195^{8}$. Ohio State University Research Foundation, 1958.

27. Thiel, E. Private communication, February 1959.

28. Vickers, W. W. Antarctic snow stratigraphy, I.G.Y. Bulletin (U.S. National Academy of Sciences), No. 23, 1959, p. 7-10. 
29. Wexler, H. Geothermal heat and glacial growth. Journal of Glaciology, Vol. 3, No. 25, 1959, p. 420-25.

30. Carslaw, H. S., and Jaeger, J. C. Conduction of heat in solids. Second edition. Oxford, Clarendon Press, 1959, p. 100.

31. Neumann, F. Lectures at University of Königsberg in early i86o's [referred to in Weber, H. Differentialgleichungen, Bd. 2, Braunschweig, 1910].

32. Stefan, J. Über einige Probleme der Theorie der Wärmeleitung. Sitzungsberichte der Kais. Akademie der Wissenschaften in Wien, Abt. 2a, Bd. 98, 1889, p. 473.

\section{APPENDIX A}

\section{Heating of an Iae Shelf, No Melting}

In Fig. Io, consider an ice shelf of thickness, $H$, whose uniform temperature at time $t=0$ is $T_{\mathrm{o}}$ and at time $t=t$ is $T=T(x)$. Take $x=0$ as the bottom of the ice shelf and positive

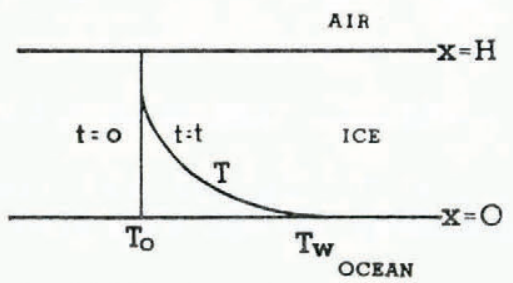

Fig. 10. Heating of an initially isothermal ice shelf over a warmer ocean, no melting

upward. Then, if $T_{w}$ is the temperature of the ocean in contact with the ice at $x=0$, and if $T_{\mathrm{o}}=$ constant at $x=H$ for all $t$, the temperature of the ice shelf is $3^{\circ}$

$$
\begin{aligned}
T=T_{w}+ & \left(T_{0}-T_{w}\right) \frac{x}{H}+\frac{2}{\pi} \sum_{\mathrm{I}}^{\infty} \frac{T_{\mathrm{o}} \cos n \pi-T_{w}}{n} \sin \frac{n \pi x}{H} \exp \left(-\kappa_{i} n^{2} \pi^{2} t / H^{2}\right)+ \\
& +\frac{2}{H} \sum_{I}^{\infty} T_{\mathrm{o}} \sin \frac{n \pi x}{H} \exp \left(-\kappa_{i} n^{2} \pi^{2} t / H^{2}\right) \int_{0}^{H} \sin \frac{n \pi x^{\prime}}{H} d x^{\prime},
\end{aligned}
$$

where $x^{\prime}$ is a running variable,

$$
\begin{aligned}
\kappa_{i}=K_{i} / \rho_{i} c_{i} & =\text { thermal diffusivity of ice }=\mathrm{I} \cdot \mathrm{I} 5 \times 10^{-2} \text { c.g.s. units } \\
K_{i} & =\text { thermal conductivity of ice }=5.3 \times 10^{-3} \\
\rho_{i} & =\text { density of ice }=0.9^{2} \\
c_{i} & =\text { specific heat of ice }=0.5
\end{aligned}
$$

After integration (I) can be reduced to

$$
\tau=T_{w}+\left(T_{0}-T_{w}\right) \frac{x}{H}+\frac{2}{\pi} \sum_{I}^{\infty} \frac{T_{0}-T_{w}}{n} \sin \frac{n \pi x}{H} \exp \left(-\kappa_{i} n^{2} \pi^{2} t / H^{2}\right) .
$$

For the range of values of interest ( $t$ of the order of $100 \mathrm{yr}$. and $H$ of the order of $100 \mathrm{~m}$.) the infinite series in (2) converges so rapidly that only three or four terms need be computed. The solutions of (2) for $H=259 \mathrm{~m}$. and $t=50,100,200$ and $400 \mathrm{yr}$. are shown in Fig. $\mathrm{I}$.

The underlying assumption in this calculation is that within the span of time considered, there is no significant change in $T_{\mathrm{o}}$. This is not true when the ice moves to warmer regions as discussed earlier. But so far as seasonal changes in temperature are concerned these are usually confined to the top $10 \mathrm{~m}$. or so of the ice shelf so that in absence of secular trends, $T_{0}$ is taken as the temperature of the ice about ro $\mathrm{m}$. below the surface.

Another important assumption, of course, is the neglect of any phase changes in the ice. Melting is considered in Appendix B. 


\section{APPENDIX B}

Heating and Melting of an Ice Shelf

In Fig. I I, consider a semi-infinite ice mass whose bottom at time $t=0$ was originally at

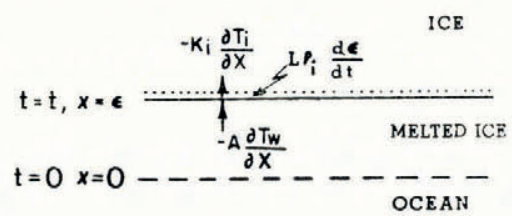

Fig. II. Heating of an initially isothermal ice half-space over a warmer ocean with melting

$x=\mathrm{o}$ but at $t=t$ is now at $x=\epsilon$. In other words, in time $t$, a layer of ice of thickness, $\epsilon$, has melted.

If $K_{i}$ is the thermal (molecular) conductivity of ice, $A$ is the eddy conductivity of sea-water and $L$ is the heat of fusion of (fresh-water) ice, there is the following exchange of energy at the ice-water interface:

$$
-A \frac{\partial T_{w}}{\partial x}=L \rho_{i} \frac{d \epsilon}{d t}-K_{i} \frac{\partial T_{i}}{\partial x} \quad \text { at } x=\epsilon .
$$

The temperature distributions in the ice and water will satisfy the Fourier heat conduction equations :

and

$$
\frac{\partial T_{i}}{\partial t}=\frac{\kappa_{i}}{\rho_{i} c_{i}} \frac{\partial^{2} T_{i}}{\partial x^{2}}=\kappa_{i} \frac{\partial^{2} T_{i}}{\partial x^{2}}
$$

$$
\frac{\partial T_{w}}{\partial t}=\frac{A}{\rho_{w} c_{w}} \frac{\partial^{2} T_{w}}{\partial x^{2}}=\kappa_{w} \frac{\partial^{2} T_{w}}{\partial x^{2}}
$$

where $A$ is assumed to be constant, and $\rho_{w}$ and $c_{w}$ are very nearly equal to unity.

The solutions are given by

and

$$
T_{i}=B_{i}+D_{i} \Phi\left(x \eta_{i}\right)
$$

where the $B$ 's and $D$ 's are constant, and

$$
T_{w}=B_{w}+D_{w} \Phi\left(x \eta_{w}\right)
$$

$$
\begin{gathered}
\eta_{i}=\frac{\mathrm{I}}{2 \sqrt{ }\left(\kappa_{i} t\right)}, \quad \eta_{w}=\frac{\mathrm{I}}{2 \sqrt{ }\left(\kappa_{w} t\right)} \\
\Phi(x) \text { is the error function, }=\frac{2}{\sqrt{ } \pi} \int_{0}^{x} \exp \left(-\beta^{2}\right) d \beta .
\end{gathered}
$$

The boundary conditions are

for ice: $\quad$ at $x=\epsilon, \mathcal{T}_{i}=0=$ freezing point of sea-water,

$$
x=\infty, T_{i}=T_{\mathrm{o}}, \text { a constant }
$$

for water: at $x=\epsilon, T_{w}=0$,

$$
x=\mathrm{o}, T_{w}=\text { Constant }=C \text {. }
$$


Then, as shown by Neumann, ${ }^{3 \mathrm{I}}$ the only non-trivial solution satisfying (4) and (5) and the boundary conditions, requires that

The solutions then become

$$
\epsilon=b \sqrt{ } t, \quad b=\text { constant. }
$$

$$
T_{i}=T_{\mathrm{o}} \frac{\Phi\left(x / 2 \sqrt{\kappa_{i} t}\right)-\Phi\left(b / 2 \sqrt{\kappa_{i}}\right)}{\mathrm{I}-\Phi\left(b / 2 \sqrt{\kappa_{i}}\right)}
$$

and

where

$$
T_{w}=C\left[\mathrm{I}-\frac{\Phi\left(x / 2 \sqrt{\kappa_{w} t}\right)}{\Phi\left(b / 2 \sqrt{\left.\kappa_{w}\right)}\right.}\right]
$$

$$
\kappa_{w}=A / \rho_{w} c_{w} \sim A .
$$

By inspection (12) and (13) are seen to satisfy the boundary conditions (9) and (10).

Differentiating (12) and (13) with respect to $x$ and substituting in the energy exchange equation (3), we arrive at

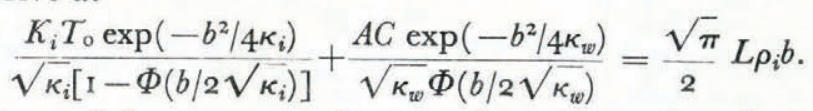

If the temperature of the sea-water is everywhere "just above" the freezing point of sea-water (taken as $0^{\circ} \mathrm{C}$. for convenience) then in (3) the term on the left side vanishes. If we assume further, that the energy used in melting the ice is exactly equal to that used in heating the ice, i.e. $-K_{i} \frac{\partial T_{i}}{\partial x}=L \rho_{i} \frac{d \epsilon}{d t}$, (I4) reduces to

$$
-\frac{\kappa_{i} T_{\circ} \exp \left(-b^{2} / 4 \kappa_{i}\right)}{\sqrt{\kappa_{i}}\left[\mathrm{I}-\Phi\left(b / 2 \sqrt{\left.\kappa_{i}\right)}\right]\right.}=\frac{\sqrt{\pi}}{2} L \rho_{i} b
$$

which leads to Stefan's solution,,$^{32}$ a special case of Neumann's solution.

When (15) is solved for $b$ and the value inserted in (12), it gives the solution for the first case, referred to in the preceding text, and is the equation from which curve "b" in Fig. I was drawn.

Equation (14) which does not assume uniform "freezing" temperature of the water nor equipartition of energy, gives the solution for the second case, and is the equation from which curves "c" and "d" in Fig. 2 were drawn. Since equation (I4) is transcendental, the solution for $b$ must be sought numerically after values have been substituted for the physical constants, $K_{i}, A, \kappa_{i}, \kappa_{w}, L, \rho_{i}$ and for the boundary temperatures, $T_{0}$ (of ice) and $C$ (of seawater).

The curves of constant melt shown in Fig. 4 as functions of $\Delta T$ (deviation of sea-water temperature from its freezing point at $x=0$ ) and $A$ (eddy conductivity of sea-water), were drawn from (14) for $t=100$ and $200 \mathrm{yr}$., under the assumption that $T_{0}$, the initial (and uniform) temperature of the ice shelf was $20.5^{\circ} \mathrm{C}$. below the freezing point of sea-water (assumed for convenience in these calculations to be $0^{\circ} \mathrm{C}$.). The parameter, $b=\epsilon / \sqrt{ } t$, is constant along a curve of constant melt. Since the thickness of the melted ice varies with $\sqrt{ } t$, the curves in Fig. 4 may be re-labeled for any time, $t$ yr., by multiplying the Ioo yr. melt amounts by $\sqrt{ } t /$ Io.

So long as one selects pairs of values, $\Delta T$ (or $C$ ) and $A$, from the same curve of equal melt in Fig. 4 (along which $b$ is constant), the temperature distributions in the ice and water $(x \geqslant 0), T_{i}$ and $T_{w}$, for any time, $t$, will be the same regardless of the choice of $\Delta T$ or $A$, as may be seen by inspection of equations (12) and (13). 